\title{
THE ROLE OF PARKING PRICING AND PARKING AVAILABILITY ON TRAVEL MODE CHOICE
}

\author{
by \\ Seyedmohsen Alavi \\ Master of Urban and Regional Planning, AUI, 2008 \\ BSc. Civil Engineering, IAU, 2002 \\ A Major Research Paper \\ presented to Ryerson University \\ in partial fulfillment of the requirements for the degree of \\ Master of Planning \\ in \\ Urban Development
}

Toronto, Ontario, Canada, 2016

(C) Seyedmohsen Alavi, 2016 
$\underline{\text { AUTHOR'S DECLARATION }}$

I hereby declare that I am the sole author of this MRP. This is a true copy of the MRP, including any required final revisions.

I authorize Ryerson University to lend this MRP to other institutions or individuals for the purpose of scholarly research.

I further authorize Ryerson University to reproduce this MRP by photocopying or by other means, in total or in part, at the request of other institutions or individuals for the purpose of scholarly research.

I understand that my MRP may be made electronically available to the public. 


\title{
THE ROLE OF PARKING PRICING AND PARKING AVAILABILITY ON TRAVEL MODE CHOICE
}

(C) Seyedmohsen Alavi, 2016

Master of Planning

in

Urban Development

Ryerson University

\begin{abstract}
This research examines the impact of parking pricing and parking availability on potential travel mode substitution among current drivers, in four case study areas in the Greater Toronto Area (GTA). It serves to evaluate opportunities to decrease private vehicle usage among the GTA's workforce. More specifically, the objective of this study is to analyze whether and to what extent parking pricing and parking availability alter drivers' willingness to change their mode of transportation. Results from ordered logit models demonstrated that a driver's willingness to change their mode of transportation was statistically correlated with parking cost and parking availability. Parking availability also impacted the correlation between parking pricing and drivers' willingness to change their mode of transportation. The results from this MRP suggests that interventions focused on reducing driving for commuting purposes may focus on changing parking pricing, but depending on the availability of parking, the impacts of such policy/ program may be different.
\end{abstract}

Keywords: Parking pricing, parking availability, driver's willingness to change, travel mode. 


\section{ACKNOWLEDGEMENTS}

I would like to offer my special thanks and heartfelt appreciation to my advisor, Professor Raktim Mitra at Ryerson University who helped me tremendously throughout this research. Without his support, this research would not have been possible.

I would also like to thank my second reader Professor David Amborski for his support and guidance.

I would like to thank Professor Pamela Robinson, Professor Nina-Marie Lister, Professor Ron Keeble and all other Faculty members of The School of Urban and Regional Planning at Ryerson University for their support. I am grateful for all the time I spent in Planning School.

In addition, I would like to thank Mayor of Richmond Hill, Dave Barrow for his support.

Also, I am grateful for the support, that I have received from Julia Macan and all my colleagues at Ryerson University.

Finally, I dedicate this research to my wife and my best friend, Sherli who has always been supportive in my life. 


\section{TABLE OF CONTENTS}

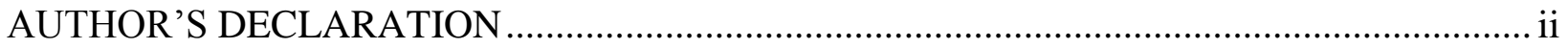

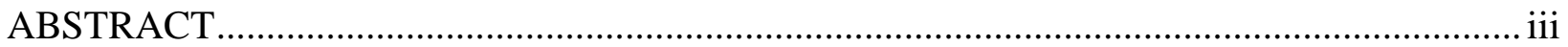

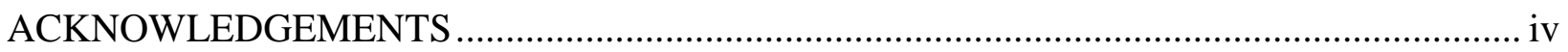

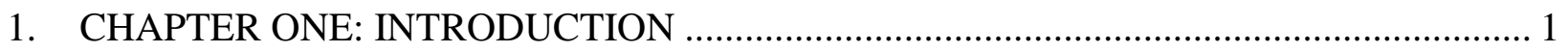

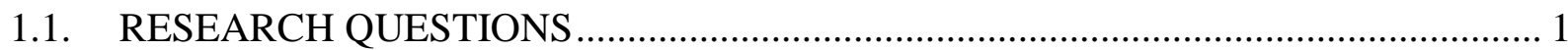

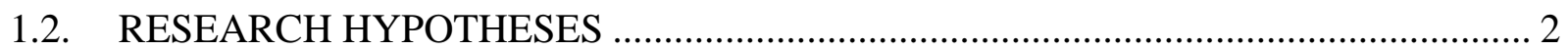

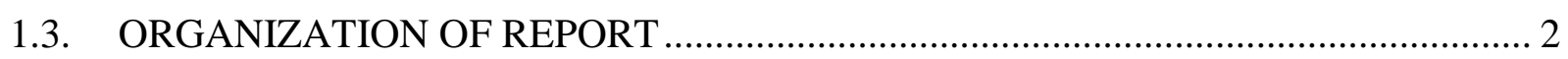

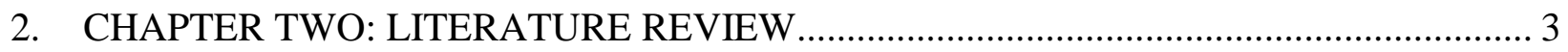

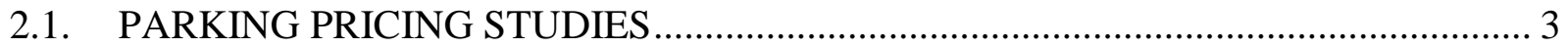

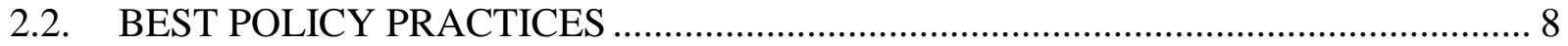

2.2.1. LONDON, UK AND SAN FRANCISCO, USA …................................................... 8

2.2.2. SAN FRANCISCO, CALIFORNIA, USA …………………………………........ 9

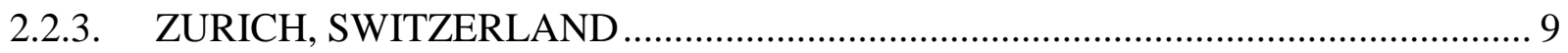

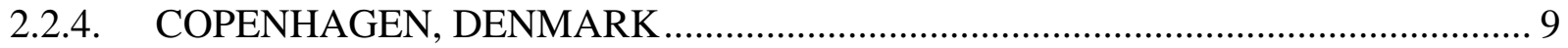

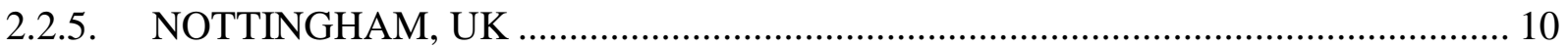

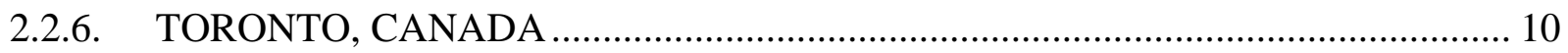

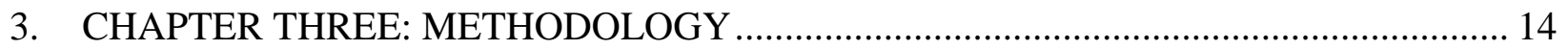

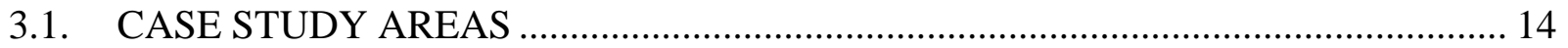




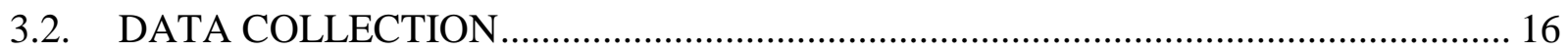

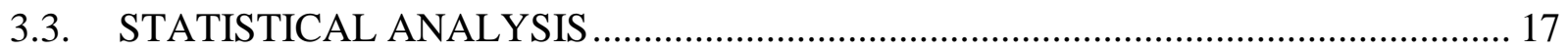

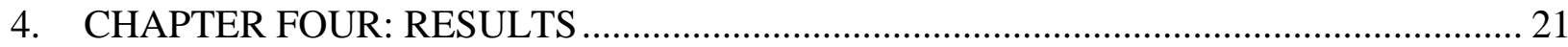

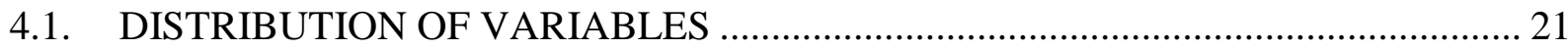

4.1.1. CATEGORY ONE: TWO-DOLLAR INCREASE ................................................. 26

4.1.2. CATEGORY TWO: FOUR-DOLLAR INCREASE ………………………........... 26

4.1.3. CATEGORY THREE: EIGHT-DOLLAR INCREASE …………………….......... 26

4.1.4. CATEGORY FOUR: TWELVE-DOLLARS INCREASE ........................................ 27

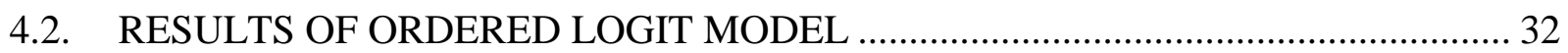

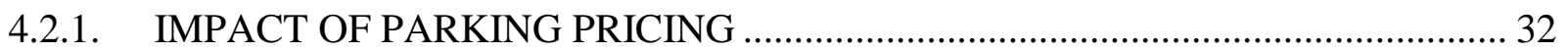

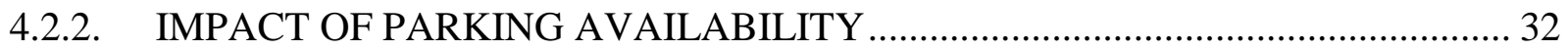

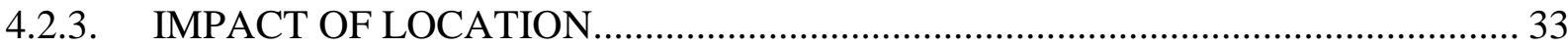

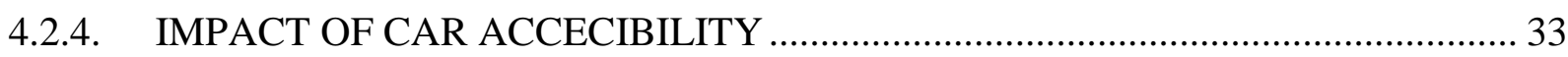

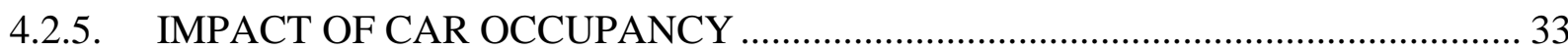

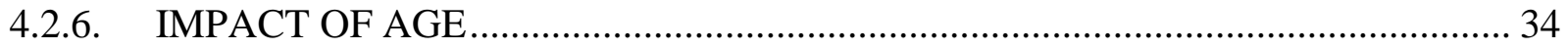

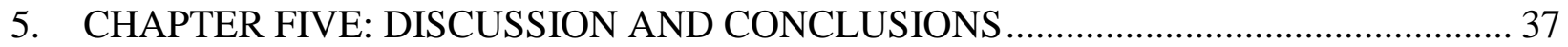

5.1 MODE SUBSTITUTION IS MORE LIKELY TO OCCUR FOR DRIVERS WHO

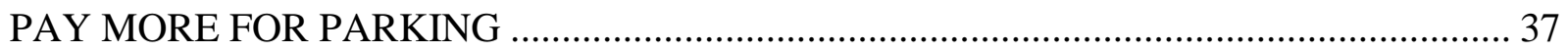

5.2. PARKING AVAILABILITY MODERATES THE RELATIONSHIP BETWEEN PARKING PRICING AND A DRIVER'S WILLINGNESS TO CHANGE THEIR MODE . 38 


\section{$\underline{\text { LIST OF TABLES }}$}

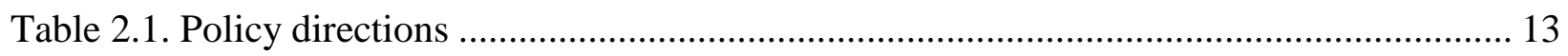

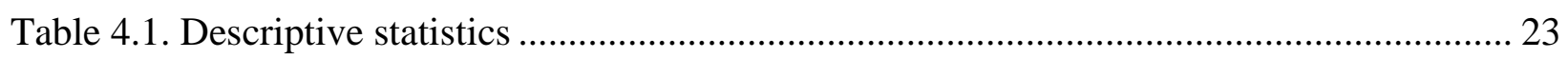

Table 4.2. Potential impact of parking pricing on travel mode ............................................ 30

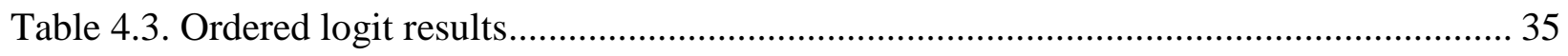

\section{$\underline{\text { LIST OF FIGURES }}$}

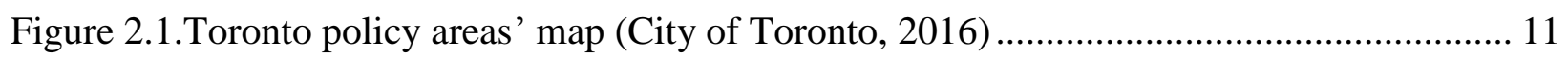

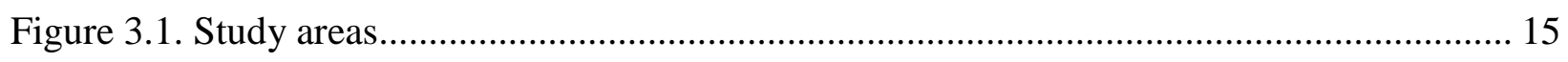

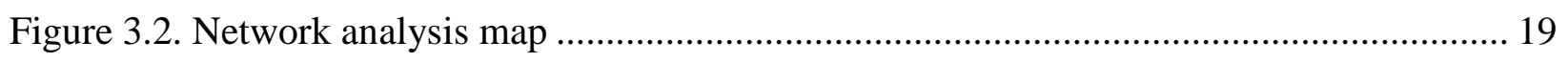

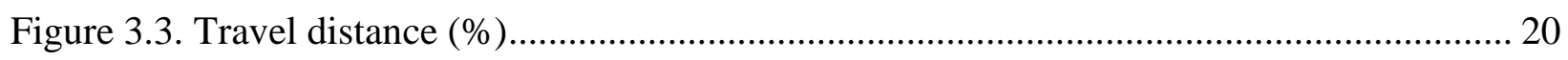

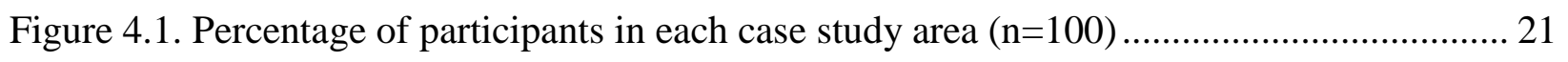

Figure 4.2. Time taken to find unoccupied parking space in case study areas ......................... 25

Figure 4.3. Percentage of transportation mode change .................................................... 28

\section{LIST OF APPENDICES}




\section{CHAPTER ONE: INTRODUCTION}

High congestion levels in some urban areas are partly related to travelers' over-dependence on privately owned automobiles (D'Acierno, Gallo, \& Montella, 2006; de Palma \& Lindsey, 2011). For example, Toronto is ranked as the eighth most congested city in North America, and the second most congested in Canada, with congestion costs of \$2.01 billion (Metrolinx, 2015; Toronto Community Foundation, 2015; Urban Transportation Task Force, 2012). Only 29\% of Toronto's employed workforce use a mode of transportation other than their private vehicles to get to work. The main objective of this study is to analyze whether and to what extent parking pricing and parking availability may be related to a commuters' preferred mode of transportation. At a broader level, the goal of this research is to examine if altered current parking pricing can shift commuters' travel modes from driving to the use of other sustainable modes such as public transportation.

\subsection{RESEARCH QUESTIONS}

I. What is the impact of increasing parking pricing on commuters' willingness to change their mode of transportation/?

II. Is drivers' willingness to change their mode of transportation, in response to parking cost increase, related to current parking cost?

III. Does the availability of parking areas influence the relationship between parking pricing increase and drivers' willingness to change their mode of transportation?

IV. Is there any difference in drivers' willingness to substitute their travel mode, between urban and suburban areas? 
This study will focus on four areas in the GTA; Liberty Village, Downtown Toronto, North York, and Richmond Hill, as case studies.

\subsection{RESEARCH HYPOTHESES}

There are two major assumptions, which are unique to the context of the case study areas. Firstly, it is hypothesized that low parking prices would relate to a commuter's willingness to drive their own vehicle more often. Furthermore, it is assumed that the relationship between parking pricing and drivers' willingness to drive would be influenced by the availability of parking spots. For instance, an area with ample parking availability, resulting in a higher chance of finding an empty parking space, people may still be willing to use their vehicles, and would accept an increase in parking costs. On the other hand, an area where it is already very difficult to find an empty parking space, people may prefer to change their mode of transportation, instead of accepting an increase in pricing.

\subsection{ORGANIZATION OF REPORT}

This research report is organized into five chapters. Chapter one provides an introduction to the research problem. The research questions, research hypotheses and the importance of the study are also discussed in chapter one. Chapter two presents a literature review. Chapter three explains the methodology, statistical modeling, and ordered logit model. Chapter four presents the results of ordered model and chapter five concludes this study. 


\section{CHAPTER TWO: LITERATURE REVIEW}

Unfortunately, In the field of urban and transportation planning, impacts of parking pricing and parking availability, although fundamental, continues to be one of the least studied topic. The following sections provide a brief description of the academic literature and professional reports that have considered parking pricing or parking availability category, along with a summary of important outcomes of them.

\subsection{PARKING PRICING STUDIES}

In recent years, several studies about parking pricing or parking availability on travel mode choice have been conducted. However, studies about parking pricing and parking availability effects on the willingness to give up driving, i.e., a potential travel mode substitution, are limited. Impacts of parking pricing and parking availability on travel mode have not yet been examined comprehensively especially in the GTA. This section summarizes the literature review of most related parking pricing studies that examined its impact on travel mode.

Previous studies that have explored parking pricing impact on travel mode suggest a potential relationship between pricing and use of different modes of transportation (Bao, Deng, \& $\mathrm{Gu}$, 2010; D'Acierno, Gallo, \& Montella, 2006; Deakin \& Harvey, 1996; Gillen, 1977; Hess, 2001; Kuzmyak et al., 2003; Ng, 2014; Willson \& Shoup, 1990). Furthermore, Current studies about parking pricing have also focused on its impact on parking demand (Gragera \& Albalate, 2016; Mackowski, Bai, \& Ouyang, 2015), and very few studies (Hess, 2001; Ng, 2014) have analyzed the long-term impacts of parking pricing on commuters' willingness to use other modes of transportation. 
Most studies that focused on parking pricing examined pricing impacts on parking demand. $(\mathrm{Ng}$, 2014). As (Deakin \& Harvey, 1996) argue, increasing parking prices hikes the overall cost of travelling by car, which could cause a variety of changes in travel choices. They evaluated a number of pricing policies in several cities in the United States and compared them with some other countries like Britain, Japan, France and Denmark. They found that pricing policies were associated with factors such as travel mode choice, car ownership and time of the trip. Furthermore, increasing parking cost was found to be effective in decreasing vehicle drive-alone mode. Similarly, Bao et al. (2010) found a significant link between the residents' travel modes and parking rates.

Willson and Shoup (1990) analyzed the studies of parking subsidies and their impact on travel behaviour. They argue that parking subsidies significantly increased solo driving. Hess (2001) supports the view that free parking affects the mode choice. Using data from the Oregon and Southwestern Washington 1994 Activity and Travel Behavior Survey, Hess (2001) predicted that with free parking, most of the commuters would choose the private car mode. He estimated a multinomial logit model of mode choice for the work trip to Portland's central business district (CBD) to examine daily commuting behavior, which suggested that a daily parking charge will increase the public transportation mode. Furthermore, Ng (2014) examined the impact of parking pricing by considering several factors such as payment type, transit incentives, parking location, income, and the willingness to walk.

The result offered by $\mathrm{Ng}$ (2014) suggests that parking pricing has a significant impact on travel mode choice, particularly in an environment where the private car users have limited parking alternatives. 
Some researchers such as Auchincloss, Weinberger, Aytur, Namba, and Ricchezza (2015) argue that transit miles moderately to strongly positively correlate with parking pricing. They found that high parking costs were significantly associated with public transit usage in larger cities.

Changing parking policies could potentially help to increase the use of other modes of transportation such as public transit. $\mathrm{Ng}$ (2014) suggested that travelers commuting shorter distances were more likely to change their mode of transportation when parking policies changed in favor of increasing the parking costs. Furthermore, Parking policies can create more flexible income for municipalities and private operators, and at the same time serve as tools to support economic success ( $\mathrm{Ng}, 2014)$.

One of the most interesting approaches to this subject has been proposed by Shoup (2011), he argues that in the United States, parking is mostly underpriced or totally free of charge for users such as employees or customers in some commercial districts.

Shoup (2005) examined the effects of underpriced parking in the U.S and found that underpriced and free ample off-street parking annually costs $\$ 127$ billion to $\$ 374$ billion which this huge amount of money could be used to develop public infrastructures. However, (Shoup, 2011) found that the cost of meeting the parking requirements trickled down to consumers or employees, in the form of lower salaries or higher retail prices. He argues that free parking at commercial areas like big grocery stores is a price discrimination in favor of customers who use their private vehicle over those who ride public transit, walk or cycle for shopping trips.

He argues that cities need parking reform to not only increase the revenue but also reduce the discrimination against people who use other mode of transportation. 
Shoup (2011) highlights the need to parking reform in three key areas:

I. Right price for parking

II. Use parking revenue for public services

III. Change minimum parking requirements policy

However, despite the well-known potential of parking pricing, this indicator has not generally been used as a tool to manage different travel mode usage.

\section{PARKING AVAILABILITY STUDIES}

In recent years, several studies have been conducted on the impact of parking availability on travel mode such as the ones by Bridgelall (2014); Pandhe and March (2012), which indicate the relationship between parking availability and travel mode. However, these studies focused mainly on the impact of parking supply on travel mode choice, and parking cost was not considered as an important factor in their studies.

Parking availability is an important factor that influences commuter's travel mode. De Jong (2012) argues that Parking problems at working place is one of the reasons that persuade employees to change their travel mode to public transportation. He found that parking issues at workplaces would significantly influence employees to change their mode of transportation toward public transit. Furthermore, he argues that any policy change that may reduce parking capacity are often met with opposition by business owners because they overestimate the percentage of their customers that drive and use free parking or underpriced on-street parking areas. De Jong (2012) points out that this mistaken belief about parking availability and customer travel behavior has resulted in too much parking capacity that, consequently, may have increased the car mode share. Kodransky and Hermann (2011) argue that decreasing the number of 
available parking spaces and increasing the parking pricing have a significant impact on travel mode, and this policy caused a considerable shift from car mode to public transportation mode in Europe. They point out that drivers circulating to find a vacant parking area in London caused traffic problems in the city and made up 33\% of traffic in London, England. It means that decreasing the number of available parking areas works if parking pricing increased at the same time to prevent monopolizing underpriced curbside space by those who already parked in underpriced on-street parking. Researchers have also predicted potential impacts of parking availability and mode choice; Bridgelall (2014) found that in top 16 of universities that allowed private car parking inside their campuses, more than $90 \%$ of the students chose private vehicle mode of transportation. Furthermore, he found that public transportation mode increased 5.7 fold when public transit became free of charge for university students in 2001 .

Pandhe and March (2012) examined the community reaction to vehicle parking supply and the influence on mode choice, and concluded that limiting parking supply is potentially the most important method impacting commuters' travel mode choice. Moreover, they found that nonvehicle transport users had less tendency to change their mode of transportation than car users.

However, urban and suburban areas with different features such as public transportation facilities, parking policies and travel distance, could potentially have different outcomes which may change the results dramatically. Researchers argue that changing parking provision policies may help to increase the use of other modes of transportation such as public transit (Pandhe \& March, 2012; Shoup, 2011; Willson, 1995). However, ample underpriced parking can frustrate efforts to change the existing vehicle travel mode choice. Recent concerns about environmental issues, economic effects, and sustainable development have led to a worldwide acceptance of the importance of parking policies. Some of the best practices of parking policy reforms are in this 
chapter. In the long-term, parking pricing and parking provision policies could not only change the number of vehicles owned, but also the vehicle types people prefer to buy (e.g. subsidized parking pricing and providing special parking for electric or small cars could convince personal vehicle users to change the type of their cars in favor of vehicles with lower ownership costs. In the US, Hawaii and Nevada provide free and special parking for electric vehicles as a direct incentive to impact the user's choice (Jin, Searle, \& Lutsey, 2014)).

Any suggestion for parking policy reforms should consider the fundamental difference between locations. Unfortunately, geographical differences with regard to the potential impact of parking pricing or availability has not been examined extensively. This research need is one of key motivations for this research. This study emphasizes that the effect of parking availability can be different in different places, and at different price points, something that has not been extensively studied in the past.

\subsection{BEST POLICY PRACTICES}

It is commonly accepted that over-dependence on private vehicle brings unwanted negative effects such as congestion and pollution. On the other hand, private vehicle mode can potentially be controlled by a comprehensive parking policy, so as to improve the public transportation usage and ease traffic congestion. The following is a list of some of the best practices in this field.

\subsubsection{LONDON, UK AND SAN FRANCISCO, USA}

London has removed the minimum parking requirement to reduce the private vehicle usage in the city. Furthermore, some North American cities such as San Francisco have replaced 
minimum parking requirement with limits and maximums on new parking construction to reduce the negative impact of car mode (Weinberger, Kaehny, \& Rufo, 2010).

\subsubsection{SAN FRANCISCO, CALIFORNIA, USA}

In commercial districts, where parking was free for employees, parking pricing policies were changed, and workers were given the cash equivalent of a parking prerequisite instead of free parking. Where parking cash-out was offered, single occupant vehicle (SOV) mode reduced and consequently, parking demands, were decreased (Weinberger et al., 2010). Furthermore, Studies in California showed that implementing this policy, reduced driving to work by $11 \%$ (Metropolitan Area Planning Council, 2016)

According to Unbundling policy, which is being piloted in San Francisco, developers should "lease or sell parking independently of residences or commercial leases" (Weinberger et al., 2010). Therefore, they cut the parking subsidies which were paid by other users.

\subsubsection{ZURICH, SWITZERLAND}

Zurich capped the parking supply in the city to prevent additional parking areas. Furthermore, in order to balance the number of on-street parking in Zurich, when a new parking is build offstreet, then one on-street parking spot has to be removed. Consequently, there would potentially be free spaces to improve bike lanes or rapid bus routes (Kodransky \& Hermann, 2011).

\subsubsection{COPENHAGEN, DENMARK}

Copenhagen has changed their parking policy dramatically. They heavily invested in active transportation mode and its infrastructure. Based on new parking policy, the city has converted a considerable number of on-street parking spaces into public infrastructures such as pedestrian 
pathways and bike lanes. More than 400 parking spaces were removed to reduce the parking supply in Copenhagen and at the same time, the total area of pedestrian sidewalks increased by approximately 4000 square meters. Consequently, biking travel mode comprised $36 \%$ of work commuters' trips as of 2005 (Cairns \& Arros, 2014; Kodransky \& Hermann, 2011).

\subsubsection{NOTTINGHAM, UK}

Nottingham, in the UK, implemented tax policy which imposes a tax of $£ 250$ annually on companies with over ten parking lots for each parking area that they provided for their workforces(Kodransky \& Hermann, 2011). It means that employers have to charge employees for parking and consequently, private car usage will be decreased. In other cities such as Hamburg, if companies provide transit pass to their employees, then they will be allowed to provide fewer parking spaces which required by Zoning- By Law.

\subsubsection{TORONTO, CANADA}

The City of Toronto's Zoning By-law (ZBL) 569-2013, aimed at reducing the need for parking (Table 2.1). The ZBL exempts some of the commercial uses that are under 200 square metres, from having to provide minimum parking requirements. This exemption applies to the Parking requirements have been reduced in some areas.

According to the ZBL, there are four policy areas in Toronto. Policy Area 1 covers Downtown Toronto, Policy Area 2 covers a smaller area near Eglinton Avenue, both Policy Areas 3 and 4 cover several major arteries in Toronto (Figure 2.1).

In comparison with other parts of the city, these four areas have lower minimum parking requirements. 


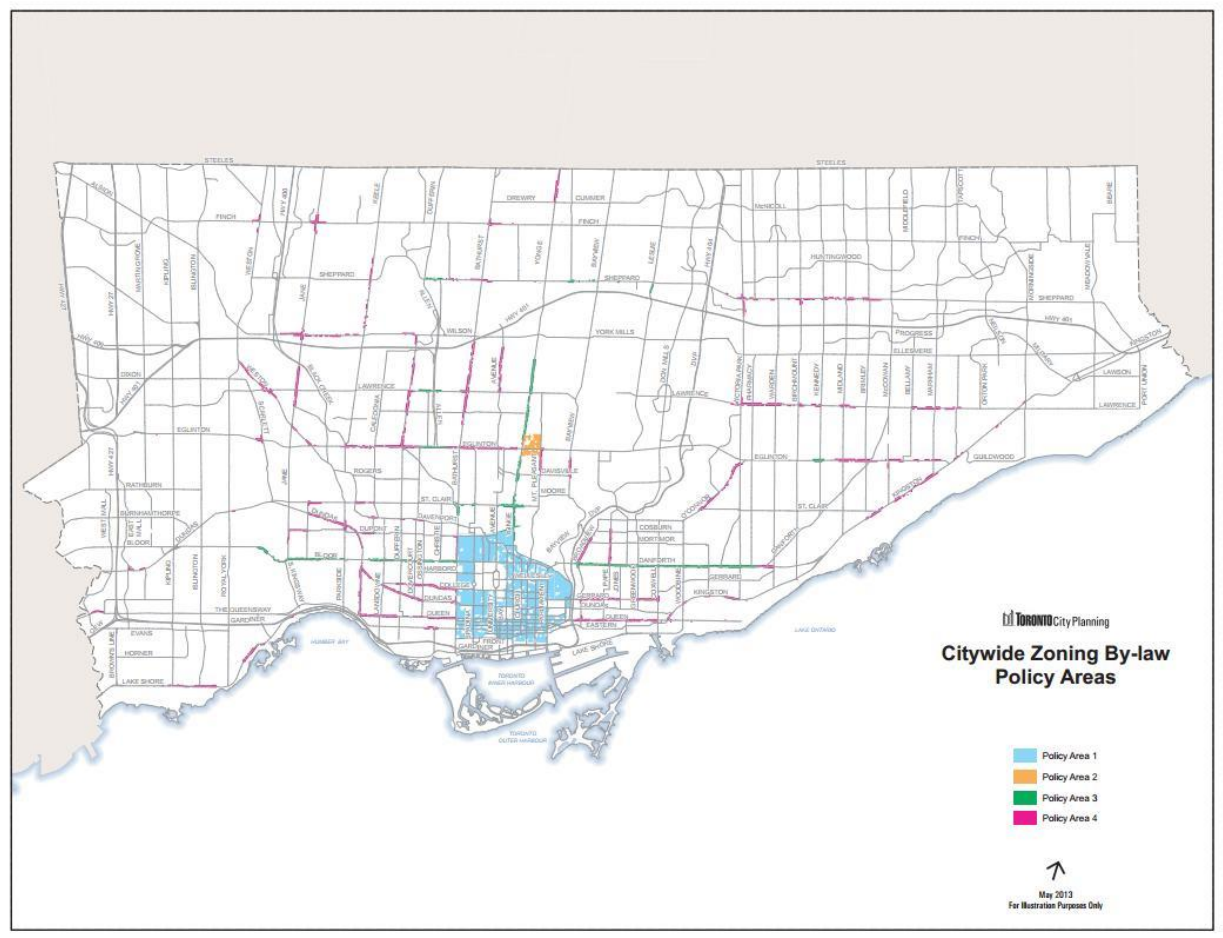

Figure 2.1.Toronto policy areas' map (City of Toronto, 2016)

The summary of important parts of policies which aimed at reducing the need for parking are as follows:

a) Eating establishments are not required to provide parking in all mentioned Policy Areas.

b) Parking spaces for hotels in all four policy areas are needed at a rate of 0.2 per 100 square metres of GFA (Gross Floor Area). The rate of 0.2 is much less than other parts of the city where 1.0 space is required for every guest room.

c) In Policy Area 1, Downtown Toronto, additional bicycle parking spaces (over and above those required by the Bylaw) may substitute for up to $20 \%$ of the required vehicular parking spaces. The exchange rate is five bicycle parking spaces for everyone vehicular parking space 
d) Minimum vehicle parking requirement may be reduced at a rate of 1 vehicle parking space for each 5 bicycle parking spaces over and above those required by the Bylaw for up to $20 \%$ of the total required vehicular parking spaces. 
Table 2.1. Policy directions

\begin{tabular}{|c|c|}
\hline Policy Title & Related Policy Statement \\
\hline $\begin{array}{l}\text { Toronto's Official Plan } \\
\text { (City of Toronto, 2015a) }\end{array}$ & $\begin{array}{l}\text { 1.4 "The Plan provides complementary policies to make more } \\
\text { efficient use of this infrastructure and to increase } \\
\text { opportunities for walking, cycling, and transit use and } \\
\text { support the goal of reducing car dependency throughout the } \\
\text { City". } \\
\text { 2.2.4 EMPLOYMENT DISTRICTS: } \\
\text { 8.b. "Encouraging new employment development to take } \\
\text { place in a form and density that supports transit and } \\
\text { discourages large areas of surface parking", }\end{array}$ \\
\hline PPS & $\begin{array}{l}\text { minimize the length and number of vehicle trips, and support } \\
\text { current and future us of transit and active transportation. }\end{array}$ \\
\hline $\begin{array}{c}\text { Growth Plan for the } \\
\text { Greater Golden } \\
\text { Horseshoe }\end{array}$ & $\begin{array}{l}\text { 2.2.2.d: "reducing dependence on the automobile through the } \\
\text { development of mixed-use, transit-supportive, pedestrian- } \\
\text { friendly urban environments" } \\
\text { 3.2.2.5:Municipalities will develop and implement transportation } \\
\text { demand management policies in official plans or other planning } \\
\text { documents, to reduce trip distance and time, and increase the } \\
\text { modal share of alternatives to the automobile. }\end{array}$ \\
\hline
\end{tabular}




\section{CHAPTER THREE: METHODOLOGY}

This research examines the role of parking pricing and parking availability on potential travel mode substitution in four areas of the Greater Toronto Area (GTA). In this research, quantitative methods and techniques were used to analyze and examine the associations between the proposed independent variables (parking pricing, parking availability, and demographics) and the dependent variable (willingness to change the travel mode) by utilizing an ordinal regression analysis technique.

This chapter begins with an overview of the case selection rationale followed by data collection methods. Methodological approaches that are relevant to the ordinal regression model are described in greater detail in statistical analysis sections.

\subsection{CASE STUDY AREAS}

Four case study areas were evaluated, namely- Downtown Toronto, Liberty Village, North York and Richmond Hill, to examine the relationship between parking pricing, parking availability and the willingness to drive among commuting drivers to these locations (Figure 3.1).

These four case study areas are appropriate because Toronto especially its Downtown section is a major employment area in the GTA. More than 587,000 jobs were placed in Downtown Toronto which consists of $43.7 \%$ of all city-wide jobs which only 47.2 of them used the public transportation (City of Toronto, 2015b; Toronto Community Foundation, 2015). 


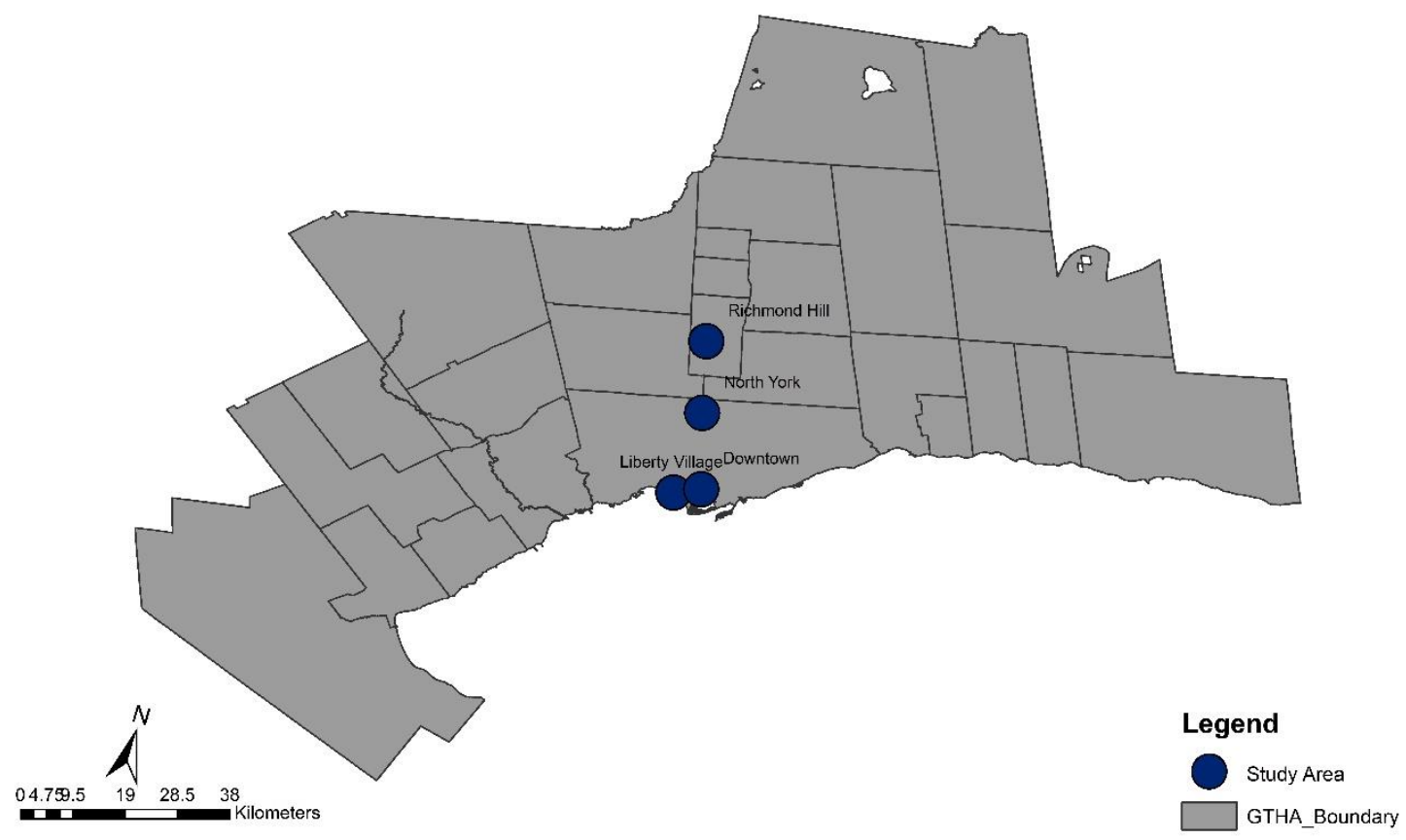

Figure 3.1. Study areas

North York Centre is another case study area which with more than 35,000 jobs, considers as the Toronto's largest employment area after Downtown (City of Toronto, 2015b). This area is the northern part of the city and can be considered to be an intermediate zone between Toronto and York Region suburban areas. In this area, research flyers were distributed along North York Centre Boundaries align Yonge Street.

Liberty Village, with more than 10,000 employees, was chosen because it is considered to be one of the most important employment areas near Downtown Toronto. Additionally, there is an ample number of off- street and on-street parking areas within Liberty Village (Alavi et al., 2016). However, Liberty Village BIA claims that shortage of parking is among the top concerns of more than 250 business owners in the area (Alavi et al., 2016). Due to these reasons, this area was selected to allow the researcher to understand the impact of parking availability and parking pricing on travel mode choice. 
Richmond Hill with suburban context was chosen because this city has different parking pricing and parking availability strategies. Unlike Downtown Toronto, in Richmond Hill, most businesses offer free parking for their employees and customers. According to the Richmond Hill Parking Strategy, the Town of Toronto is trying to increase on-street and off-street parking provision by adding more on-street parking areas and encouraging new developments to build more underground parking supply. This strategy is different from downtown Toronto parking policy which is trying to reduce minimum parking requirement. (Town of Richmond Hill, 2010).

\subsection{DATA COLLECTION}

The main data that was used for this research was collected by means of an anonymous online survey. The online questionnaire collected self-reported parking pricing data from current drivers, as well as information about parking availability in each case study areas. The Opinio survey platform, which is securely hosted in Canada and is housed on the DMP server at Ryerson University, was used to conduct the online survey. The ethics approval for this research was obtained from Ryerson University’s Research Ethics Board (REB) in May 2016.

In this research, participants who used their personal vehicles to commute to work or business were eligible to complete the online survey (APPENDIX 1). Private parking lots in the case study areas were not examined in this research, as it focuses primarily on parking areas which were accessible to the public.

Data collection for the online survey included the following steps: 1- Recruitment flyers were placed on parked cars and distributed in several parking areas within each case study location. 2The inclusion criteria and research subjects were clearly mentioned in research flyers. 3- Two thousand flyers were distributed from Monday to Thursday between 10:00 am to 12:00 pm for 
two consecutive weeks. A total of 132 drivers responded to the survey, the response rate was $6.6 \%$

Participants were asked twenty questions, relating to daily and monthly parking pricing and availability of parking in their area of work or business. In addition, the respondents provided data on their socio-economic characteristics, including, income, age and other related information that may influence their travel mode choice (APPENDIX 1). They were asked to report their information relating to the day when they received the research flyer.

Using the survey data, the spatial distribution of participants was determined by asking them to name the main intersection closest to their home and work or business area, to ensure a representative geographic spread across the case study areas.

A total of $132(n=132)$ participants completed the online survey, out of which 32 were excluded because their trip was not for work or business purposes, or questions were not completed correctly resulting in a final sample of $n=100$ that was used for further analysis.

\subsection{STATISTICAL ANALYSIS}

Ordered logit models were estimated to explore the statistical association between dependent variable " $y$ " (drivers' willingness to give up driving) and independent variables or " $\mathrm{x}$ " such as parking pricing, parking availability, age, numbers of vehicles per household, trip distance, trip duration and location.

The ordered logit model (also known as proportional odds model), is a type of regression model which is suitable for ordinal dependent variables (Mitra, Faulkner, Buliung, \& Stone, 2014). In SPSS software, the ordinal regression process is named PLUM (Polychromous Universal 
Model), PLUM is an extension of the normal linear model to ordinal categorical data (IBM Knowledge Center, 2016; O'Connell, 2005; Wikipedia contributors, 2016). The ordered logit model allowed an evaluation of multiple 'levels' of drivers' willingness to change their mode of transportation which coded as an ordinal scale. The results are presented in terms of proportional Odds Ratio (OR, i.e. $e^{\text {Coef. }}$ ), which show the association between one unite change in variable and the odds of the drivers' to be more willing to change their mode of transportation.

For example, odds ratio of 46.65 (table 4.3), indicates that participants in Downtown were much more likely to change their mode of transportation than participants who were from Richmond Hill area.

A total of nine ordered logit models were used to examine the correlates of drivers' willingness to change their mode of transportation, using SPSS software.

In order to quantify and measure commute distance and duration, nearest intersection to each participant's home and workplace were collected, and an address database was built based on geocoded data. At the next step, address database was added to the ArcGIS software and an ArcGIS Network Analyst was performed to measure distances between commuters' home and their work or business destination. Drive times and distance were evaluated using the Network Analyst extension in ArcGIS software where the route optimization was based on the shortest route between all origins and destinations and the time taken in the speed limit of the road divided by its length (Figure 3.2) 


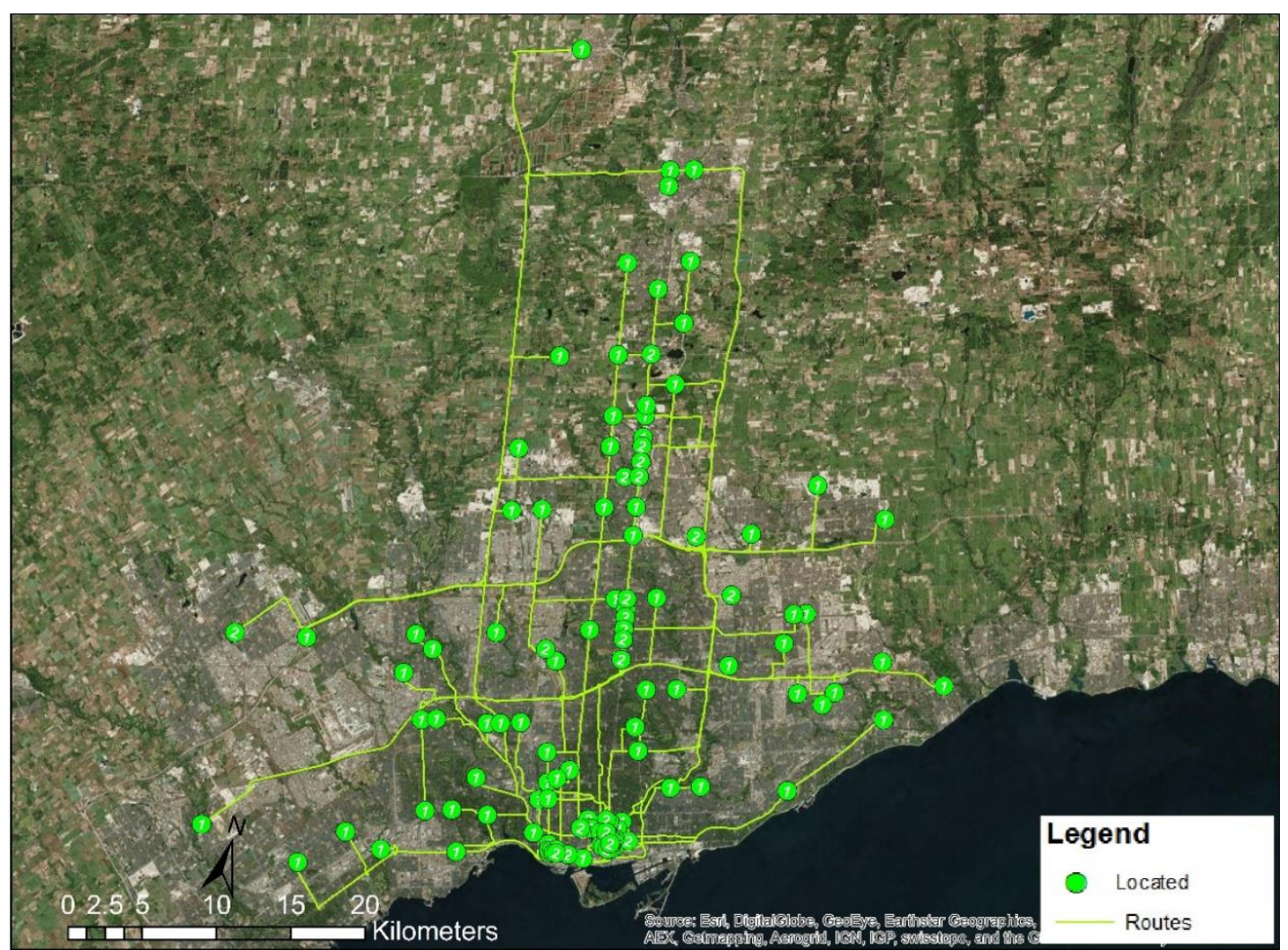

Figure 3.2. Network analysis map

The result of Network analysis shows that the majority of participants (45\%) drove between 10 $\mathrm{km}$ to $19.99 \mathrm{~km}$ with average $19.2 \mathrm{~km}$. Maximum distance was $58.9 \mathrm{~km}$, and minimum distance was $1.3 \mathrm{~km}$. Further analysis of travel distance also shows that Downtown participants drove the longest distance while Richmond Hill participants drove least (Figure 3.3). Furthermore, average travel time was 16.03 minutes with a maximum of 41.1 minutes. 


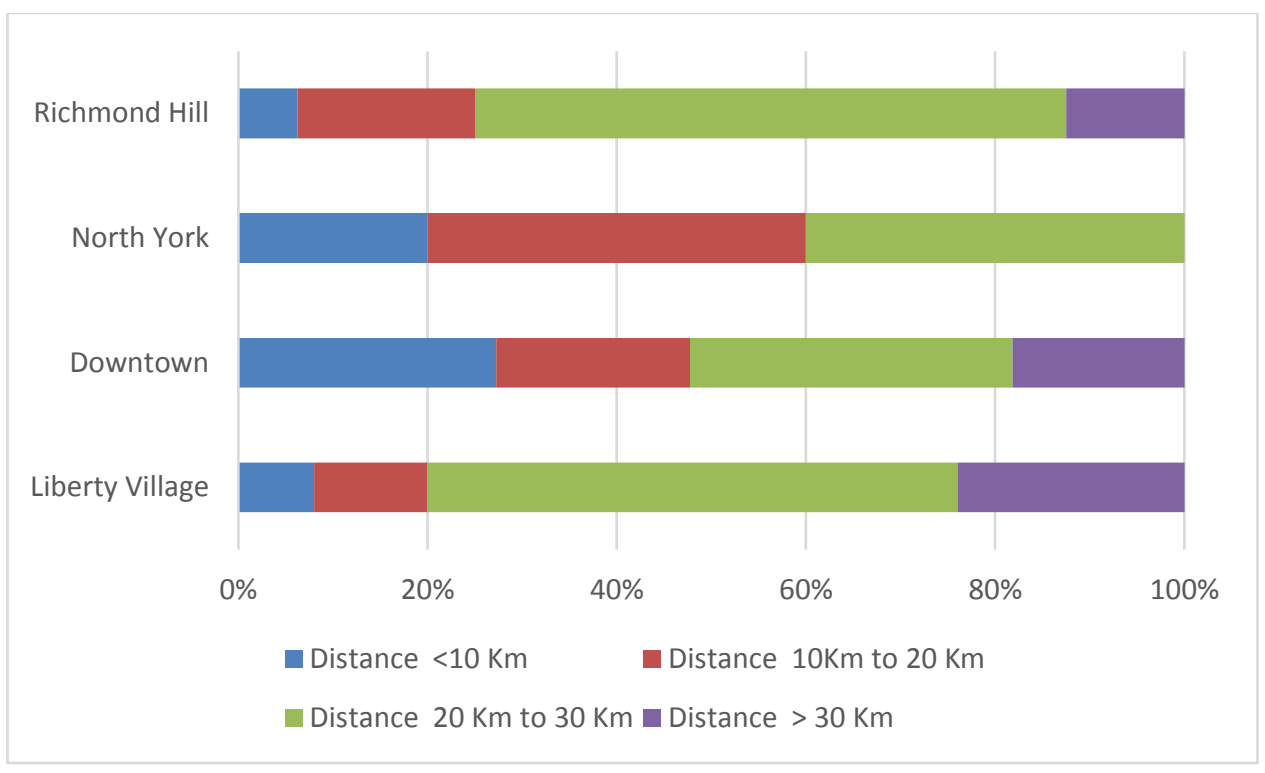

Figure 3.3. Travel distance (\%) 


\section{CHAPTER FOUR: RESULTS}

Drivers' willingness to substitute travel mode was examined using primary data from $n=100$ survey respondents. This chapter presents key empirical findings from the survey data, using descriptive statistics and ordinal regression models.

\subsection{DISTRIBUTION OF VARIABLES}

The descriptive statistics of selected variables are discussed below and are also summarized in Table 4.1

Most of the online survey forms were completed by participants from Toronto (44\%) while only $15 \%$ of the surveys were completed by participants from the North York study area (Figure 4.1).

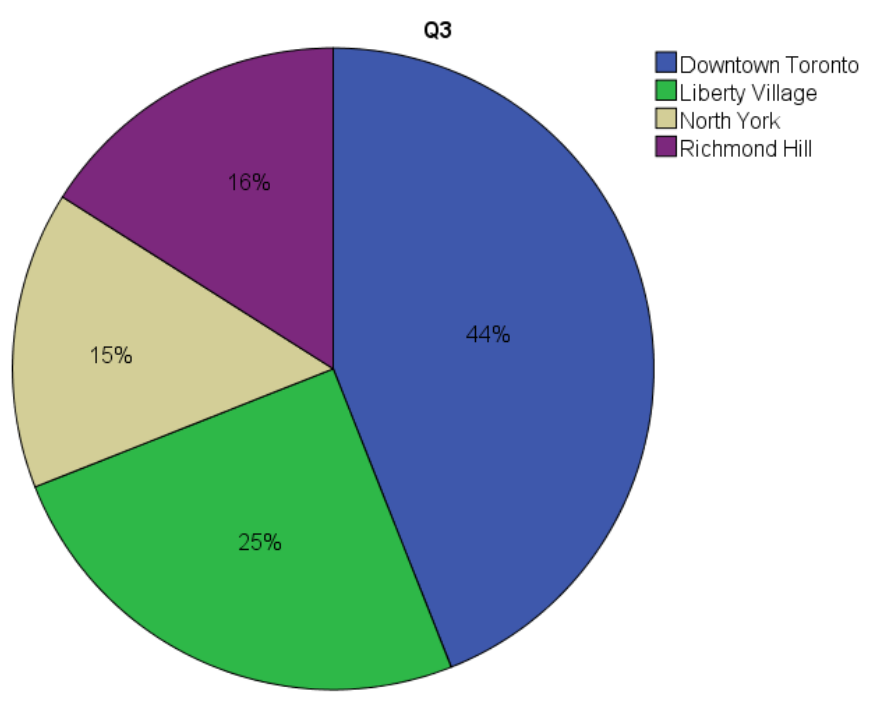

Figure 4.1. Percentage of participants in each case study area $(n=100)$ 
The largest age group is from 35 to 50 years old (44\%), followed by less than 35 years old group (36\%). Furthermore, the largest income group sampled is between $\$ 60,000$ and $\$ 79,999(36 \%)$, followed by $\$ 80,000$ to $\$ 119,999$ (35\%). $14 \%$ of the respondents reported having a household income of under $\$ 60,000$, while $9 \%$ reported having a household income of $\$ 120,000$ or greater and $6 \%$ did not mention their income.

Most of the respondents $(83 \%)$ did not drive anyone else to other place before coming to work at the day they received the research flyer, and only $17 \%$ of participants were not the alone driver.

The majority of the respondents (57\%) had two vehicles in their households, while $29 \%$ of them had one vehicle in their households and $14 \%$ of respondents had more than two cars in their households (Table 4.1) 
Table 4.1. Descriptive statistics

\begin{tabular}{|c|c|c|c|c|}
\hline & $\begin{array}{c}\text { Downtown } \\
\text { Toronto \% } \\
(\mathrm{n}=44)\end{array}$ & $\begin{array}{l}\text { Liberty } \\
\text { Village \% } \\
(n=25)\end{array}$ & $\begin{array}{l}\text { North York \% } \\
\qquad(\mathrm{n}=15)\end{array}$ & $\begin{array}{l}\text { Richmond Hill \% } \\
\qquad(\mathrm{n}=16)\end{array}$ \\
\hline Participants location & 44 & 25 & 15 & 16 \\
\hline \multicolumn{5}{|l|}{ Parking availability characteristics } \\
\hline \multicolumn{5}{|l|}{ The cruising time to find an unoccupied parking space } \\
\hline $\begin{array}{l}\text { No time at all (For example if you have a reserved } \\
\text { parking spot) }\end{array}$ & 0 & 12 & 7 & 25 \\
\hline 1 min to less than 2 min & 5 & 24 & 20 & 63 \\
\hline 2 min to less than 5 min & 9 & 64 & 73 & 13 \\
\hline $5 \mathrm{~min}$ to less than $10 \mathrm{~min}$ & 70 & 0 & 0 & 0 \\
\hline 10 minutes and more & 16 & 0 & 0 & 0 \\
\hline \multicolumn{5}{|l|}{ Time to walk from parking space to workplace } \\
\hline Less than 1 minute & 2 & 8 & 0 & 25 \\
\hline $1 \mathrm{~min}$ to less than $5 \mathrm{~min}$ & 2 & 12 & 27 & 56 \\
\hline $5 \mathrm{~min}$ to less than $10 \mathrm{~min}$ & 43 & 80 & 60 & 19 \\
\hline 10 min to less than $15 \mathrm{~min}$ & 45 & 0 & 13 & 0 \\
\hline 15 minutes and more & 7 & 0 & 0 & 0 \\
\hline \multicolumn{5}{|l|}{ Parking pricing characteristics } \\
\hline \multicolumn{5}{|l|}{ Parking cost (Daily base) } \\
\hline$\$ 0$ (parking was free) & 0 & 8 & 13 & 75 \\
\hline$\$ 1-\$ 4.99$ & 0 & 4 & 0 & 13 \\
\hline$\$ 5-\$ 9.99$ & 9 & 64 & 67 & 6 \\
\hline$\$ 10-\$ 14.99$ & 16 & 16 & 20 & 6 \\
\hline$\$ 15-\$ 19.99$ & 52 & 4 & 0 & 0 \\
\hline$\$ 20$ and more & 23 & 4 & 0 & 0 \\
\hline
\end{tabular}


Table 4.1(Continued)

\begin{tabular}{|c|c|c|c|c|}
\hline & $\begin{array}{c}\text { Downtown } \\
\text { Toronto \% } \\
(\mathrm{n}=44)\end{array}$ & $\begin{array}{c}\text { Liberty } \\
\text { Village \% } \\
(\mathrm{n}=25)\end{array}$ & $\begin{array}{l}\text { North York \% } \\
\qquad(\mathrm{n}=15)\end{array}$ & $\begin{array}{l}\text { Richmond Hill \% } \\
\qquad(\mathrm{n}=16)\end{array}$ \\
\hline \multicolumn{5}{|l|}{ Parking cost (Monthly base) } \\
\hline $0-\$ 49.99$ & 0 & 8 & 13 & 81 \\
\hline$\$ 50-\$ 99.99$ & 5 & 4 & 0 & 19 \\
\hline$\$ 100-\$ 149.99$ & 5 & 36 & 47 & 0 \\
\hline$\$ 150-\$ 199.99$ & 7 & 52 & 40 & 0 \\
\hline$\$ 200$ and more & 84 & 0 & 0 & 0 \\
\hline \multicolumn{5}{|l|}{$\begin{array}{c}\text { Participants' demographic } \\
\text { characteristics }\end{array}$} \\
\hline \multicolumn{5}{|l|}{ Age } \\
\hline Less than 35 years old & 7 & 24 & 7 & 0 \\
\hline Between 35 to 50 years old & 70 & 64 & 67 & 81 \\
\hline 50 years old and more & 23 & 12 & 27 & 19 \\
\hline \multicolumn{5}{|l|}{ Total annual household income } \\
\hline Less than $\$ 60,000$ & 7 & 40 & 7 & 0 \\
\hline$\$ 60,000$ to $\$ 79,999$ & 43 & 28 & 33 & 31 \\
\hline$\$ 80,000$ to $\$ 119,999$ & 32 & 24 & 47 & 50 \\
\hline$\$ 120,000$ and more & 14 & 4 & 7 & 6 \\
\hline Prefer not to say & 5 & 4 & 7 & 13 \\
\hline \multicolumn{5}{|l|}{ Number of cars (Household) } \\
\hline 1 car & 32 & 48 & 7 & 13 \\
\hline 2 cars & 61 & 48 & 60 & 56 \\
\hline More than 2 cars & 7 & 4 & 33 & 31 \\
\hline \multicolumn{5}{|l|}{ Parking type } \\
\hline $\begin{array}{l}\text { Public off-street parking garages or lot (where } \\
\text { anyone can park a vehicle) }\end{array}$ & 52 & 76 & 40 & 50 \\
\hline $\begin{array}{l}\text { Private off-street parking garages or lot (i.e., } \\
\text { reserved for employees of certain office/ business) }\end{array}$ & 23 & 12 & 20 & 50 \\
\hline $\begin{array}{l}\text { On-street parking } \\
\text { space }\end{array}$ & 25 & 12 & 40 & 0 \\
\hline
\end{tabular}


It is clear from the data that there is a significant difference in cruising time to find an unoccupied parking between Richmond Hill as a suburban area and Downtown area. One-quarter of participants in Richmond Hill spent "no time at all" while $86 \%$ of participants in Downtown spent more than 5 minutes to find an unoccupied parking space (Table 4.1). Furthermore, 86\% of participants in the Downtown case study area spent more than 5 minutes to walk from their parked vehicles to their workplace, while in all other case study areas, participants spent less than 5 minutes (Table 4.1). Interestingly, $63 \%$ of participants in Richmond Hill spent less than 2 minutes (Figure 4.2).

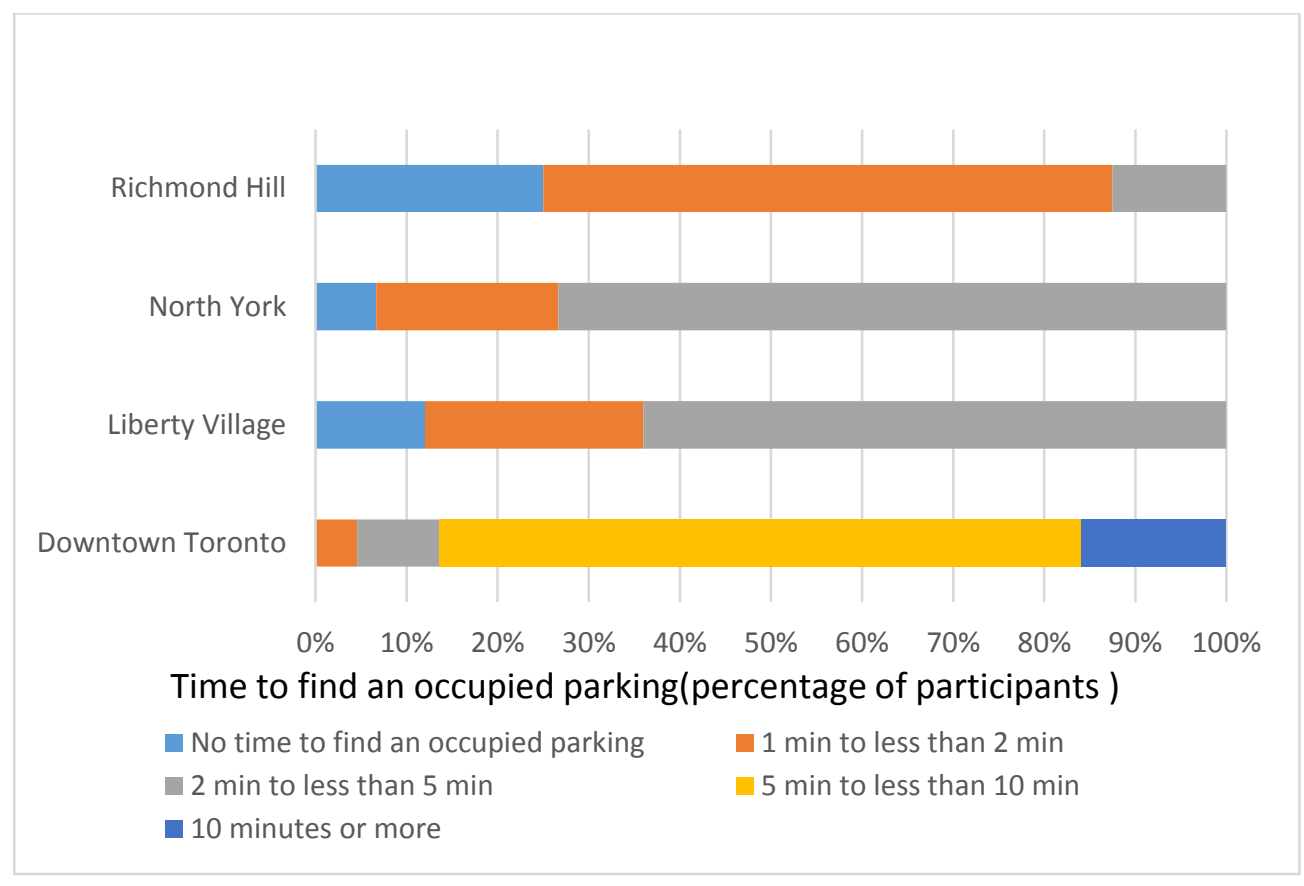

Figure 4.2. Time taken to find unoccupied parking space in case study areas

Survey respondents were asked a series of questions to explore if they would still drive to work if their daily parking costs were increased by $\$ 2$ or (25 cents per hour). Participants were asked to answer three subsequent questions relating to theor potential response due to daily parking cost increases of $\$ 4$ or (50 cents per hour), $\$ 8$ or ( $\$ 1$ per hour) and $\$ 12$ or ( $\$ 1.5$ per hour) to 
evaluate drivers' willingness to change their mode of transportation, in each scenario. If they answered "no" at any point, they were asked what their alternative mode of transportation would be.

\subsubsection{CATEGORY ONE: TWO-DOLLAR INCREASE}

Five percent of survey respondents in Downtown said they would change their mode of transportation because of parking pricing increase by two-dollars a day, half of them would use public transit and the other half would cycle as their alternative. In Liberty Village and North York, all participants who decided to change their mode of transportation would use public transportation as their alternative transportation mode. On the other hand, all participants in Richmond Hill accepted cost increase and said that they will not change their mode of transportation (Table 4.2).

\subsubsection{CATEGORY TWO: FOUR-DOLLAR INCREASE}

The majority of participants across all study areas would not change their mode of transportation if the parking pricing were increased by $\$ 4$ daily. All remaining participants in both Richmond Hill and North York, $96 \%$ of participants from the Toronto area and $98 \%$ of participants from Liberty Village said that they would not change their mode of transportation. All of them in Toronto who decided to change their mode, would use public transportation and all others from Liberty Village would use Uber Taxi as their alternative transportation mode (Table 4.2).

\subsubsection{CATEGORY THREE: EIGHT-DOLLAR INCREASE}

More than half $(51 \%)$ of Downtown participants mentioned that they would change their mode of transportation if the parking costs were increased by $\$ 8$ daily which $90 \%$ of them would use 
public transportation as their alternative. About $22.7 \%$ of participants in Liberty Village and $17 \%$ of those from North York would change their mode if parking costs were increased by $\$ 8$. Conversely, all Richmond Hill participants decided that they would not change their driving mode in this pricing scenario (Table 4.2).

This data suggests that the right parking pricing would motivate more people to change their mode of transportation from driving to other modes, especially public transportation.

\subsubsection{CATEGORY FOUR: TWELVE-DOLLARS INCREASE}

Participants who did not change their mode, were asked whether they would change their mode of transportation if parking pricing was increased by $\$ 12$ daily or ( $\$ 1.5$ per hour). $85 \%$ of participants in Downtown reported that they would change their mode of transportation while only $12 \%$ of participants in Richmond Hill chose to change their mode. $88 \%$ of Toronto participants would use public transportation and $12 \%$ would use Uber as their alternative mode and in this scenario $50 \%$ of Richmond Hill participants would use public transportation as their alternative mode.

According to the survey data, not only are there very large differences in drivers' willingness to change their mode of transportation, between Downtown and other case study areas, but this gap is also significant between Richmond Hill and the other two non-downtown urban areas (Table 4.2).

It is noticeable that parking pricing was the cheapest in Richmond Hill and this area also had ample parking space availability. Almost $75 \%$ of Richmond Hill participants had parked their vehicles in a free parking area on the day they received the research flyer, and all of them paid less than $\$ 99.99$ monthly in comparison to Downtown where no one had parked in a free parking 
area and $85 \%$ of participants paid more than $\$ 200$ monthly for parking (Table 4.2). Free parking and ample of parking lots may have influenced Richmond Hill participants' responses that was dominated by no desire to change their mode of transportation even with $\$ 12$ increase in daily parking costs.

Overall, most of the drivers $(65 \%)$ mentioned that they would change their mode of transportation if parking costs were increased. With regard to geographical variation, $41 \%$ of respondents who drove to Downtown Toronto would potential substitute their current travel mode, followed by Liberty Village (14\%) and North York (8\%). Only $2 \%$ of those who drove to Richmond Hill would change their mode if parking prices went up (Figure 4.3). Of those who would not substitute their current travel mode, most (97\%) believed that driving mode would still be the cheapest mode even after a parking cost increase of a $\$ 12$ day, while 3\% mentioned that no other alternative was available for them if they had to change their current mode or travel.

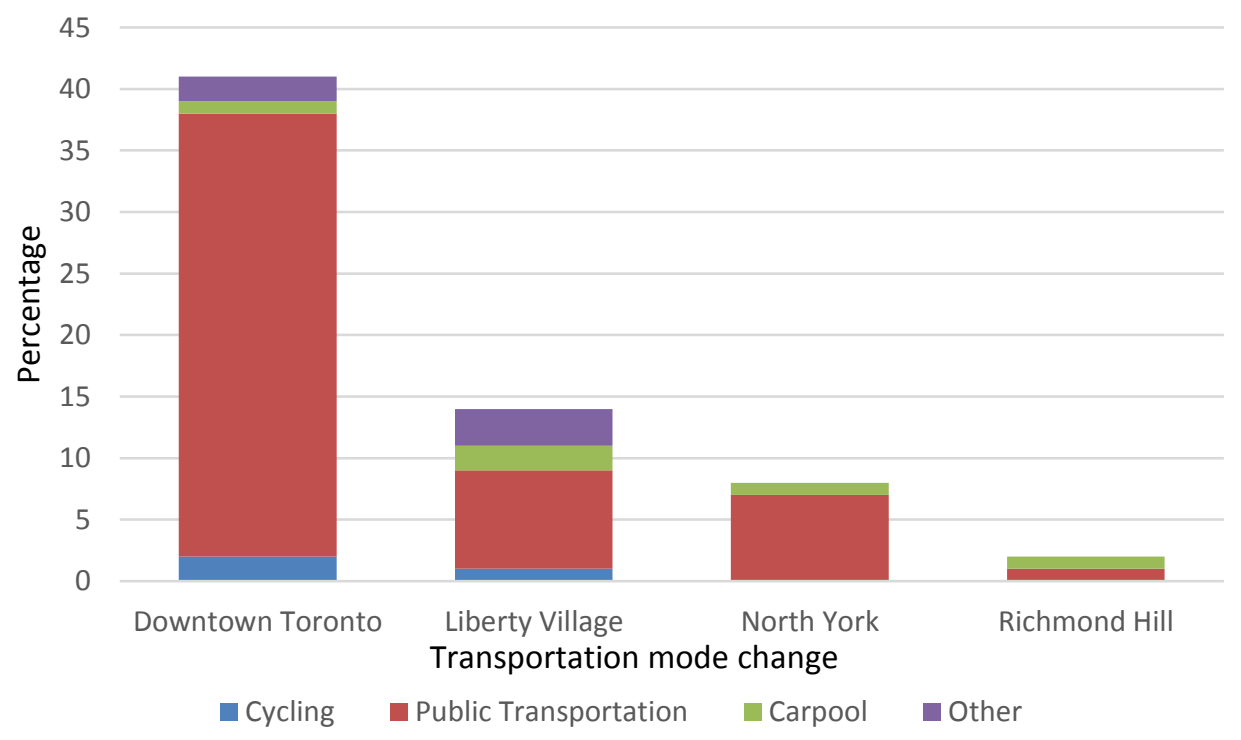

Figure 4.3. Percentage of transportation mode change, categorized by alternative modes $(n=65)$ 
The next section of this report examines the potential influence of parking pricing and parking availability on drivers' willingness to change their mode of transportation more systematically. 
Table 4.2. Potential impact of parking pricing on travel mode

\begin{tabular}{|c|c|c|c|c|c|c|c|c|c|c|c|}
\hline & & & \multirow{2}{*}{$(n=100)$} & \multicolumn{2}{|c|}{ Downtown Toronto } & \multicolumn{2}{|c|}{ Liberty Village } & \multicolumn{2}{|c|}{ North York } & \multicolumn{2}{|c|}{ Richmond Hill } \\
\hline & & & & Frequency & $\%$ & Frequency & $\%$ & Frequency & $\%$ & Frequency & $\%$ \\
\hline \multirow{4}{*}{ 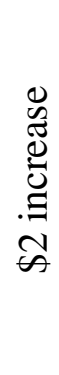 } & 苂 & Mode shift & & 2 & 5 & 2 & 8 & 1 & 7 & 0 & 0 \\
\hline & Еँّ & No change & & 42 & 95 & 23 & 92 & 14 & 93 & 16 & 100 \\
\hline & 恶 & Cycling & & 1 & 50 & 0 & 0 & 0 & 0 & 0 & 0 \\
\hline & \begin{tabular}{ll}
$\bar{\Xi}$ & $\Xi$ \\
\multirow{2}{*}{} & 0
\end{tabular} & $\begin{array}{c}\text { Public } \\
\text { Transportation }\end{array}$ & & 1 & 50 & 2 & 100 & 1 & 100 & 0 & 0 \\
\hline \multirow{5}{*}{ 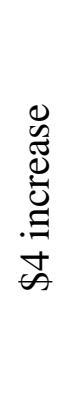 } & 苨. & Mode shift & & 1 & 2 & 0 & 4 & 0 & 0 & 0 & 0 \\
\hline & ฮี & No change & & 41 & 98 & 0 & 96 & 0 & 100 & 0 & 100 \\
\hline & & Cycling & & 0 & 0 & & & & & & \\
\hline & 芯 & Public & & 1 & 100 & & & & & & \\
\hline & 昰 & Other & & & & 1 & 100 (Uber) & & & & \\
\hline \multirow{6}{*}{ 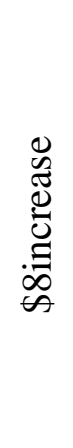 } & $\stackrel{\mathscr{0}}{\stackrel{\Xi}{\Xi} .0 ี ~}$ & Mode shift & & 21 & 51 & 5 & 23 & 2 & 14 & 0 & 0 \\
\hline & Еँ & No change & & 20 & 49 & 17 & 77 & 12 & 86 & 16 & 100 \\
\hline & & Cycling & & 1 & 5 & 1 & 20 & 0 & 0 & 0 & 0 \\
\hline & 胥 & $\begin{array}{c}\text { Public } \\
\text { Transportation }\end{array}$ & & 19 & 90 & 2 & 40 & 2 & 100 & 0 & 0 \\
\hline & $\stackrel{\Phi}{\Xi} \Xi$ & Carpool & & 1 & 5 & 1 & 20 & & & & \\
\hline & & Other & & 0 & 0 & 1 & 20 (Uber) & & & & \\
\hline
\end{tabular}


Table 4.2. (Continued)

\begin{tabular}{|c|c|c|c|c|c|c|c|c|c|c|c|}
\hline & & & \multirow[b]{2}{*}{$(\mathrm{n}=100)$} & \multicolumn{2}{|c|}{ Downtown Toronto } & \multicolumn{2}{|c|}{ Liberty Village } & \multicolumn{2}{|c|}{ North York } & \multicolumn{2}{|c|}{ Richmond Hill } \\
\hline & & & & $\begin{array}{c}\text { Frequenc } \\
\mathrm{y} \\
\end{array}$ & $\%$ & $\begin{array}{c}\text { Frequenc } \\
\mathrm{y} \\
\end{array}$ & $\%$ & $\begin{array}{c}\text { Frequenc } \\
\mathrm{y} \\
\end{array}$ & $\%$ & $\begin{array}{c}\text { Frequenc } \\
\mathrm{y} \\
\end{array}$ & $\%$ \\
\hline \multirow{5}{*}{ 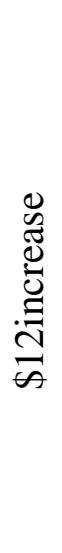 } & 芯. & Mode shift & & 17 & 85 & 6 & 35 & 5 & 42 & 2 & 12 \\
\hline & 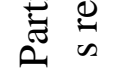 & No change & & 3 & 15 & 11 & 65 & 7 & 58 & 14 & 88 \\
\hline & $\stackrel{\mathscr{Z}}{0}$ & $\begin{array}{c}\text { Public } \\
\text { Transportation }\end{array}$ & & 15 & 88 & 4 & 66 & 4 & 80 & 1 & 50 \\
\hline & 胥 & Carpool & & 0 & 0 & 1 & 17 & 1 & 20 & 1 & 50 \\
\hline & $\ll$ & Other & & 2 & 12(Uber) & 1 & 17 & & & & \\
\hline
\end{tabular}




\subsection{RESULTS OF ORDERED LOGIT MODEL}

The results of ordered logit model are presented in this section. Ordered logit analysis shows that several aspects of the parking pricing and parking availability were significantly correlated with drivers' willingness to change their mode of transportation score (Table 4.3)

\subsubsection{IMPACT OF PARKING PRICING}

The ordered logit analysis shows that drivers who paid $\$ 20$ or more per day on parking were much more likely to change their mode of transportation $(\mathrm{OR}=16.14)$ than participants who were parked in a free parking area (Table 4.3, model 2). Furthermore, drivers who paid $\$ 10$ to $\$ 19.99$ were more likely to change their mode $(\mathrm{OR}=10.87)$. According to the model, participants who paid less than $\$ 10$ were more likely to change their mode of transportation $(\mathrm{OR}=3.52)$ than drivers who parked free of cost. Results suggest that increasing parking pricing would increase the drivers' willingness to shift their mode of transportation. Furthermore, the model result suggests that participants who paid less (Richmond Hill) were less likely to change their mode. It shows that drivers' willingness to change their mode of transportation, in response to parking cost increase, is significantly related to current parking costs.

\subsubsection{IMPACT OF PARKING AVAILABILITY}

The ordered logit model shows that participants who spend ' 0 to less than 2 min' to find an unoccupied parking area were less likely to change their mode of transportation $(\mathrm{OR}=0.13)$ compared with participants who spent "5 minutes and more".

The analysis suggests that there is a relationship between duration to find an unoccupied parking lot, used here as a measure of parking availability, and drivers' willingness to change their mode 
of transportation. Results of the model indicates that parking availability may influence the relationship between parking pricing and drivers' willingness to substitute their current travel mode. The results suggest that more available parking would influence odd ratio of drivers' willingness to change their mode in case of parking costs increase (Table 4.3, Model 4)

\subsubsection{IMPACT OF LOCATION}

Participants in Downtown were much more likely to change their mode of transportation than participants who were from Richmond Hill area $(\mathrm{OR}=46.65)$. Similarly, odds ratios show that participants from Liberty Village $(\mathrm{OR}=13.01)$ and North York $(\mathrm{OR}=8.87)$ were more likely to change their mode of transportation than Richmond Hill participants. The results indicate that there were statistically significant associations between location and drivers' willingness to change their mode of transportation (Table 4.3, model 1). In addition, it shows that drivers' willingness to change their mode of transportation is different in urban and suburban areas.

\subsubsection{IMPACT OF CAR ACCECIBILITY}

Ordered logit model shows that there was a significant relationship between access to cars and drivers' willingness to change their mode of transportation. It indicates that commuters with one car were more likely to change their mode of transportation(OR=6.98) than participants with more than two cars in their household (Table4.3, model 6). Thus, commuters who have more car accessibility are less likely to give up driving.

\subsubsection{IMPACT OF CAR OCCUPANCY}

Result suggests that drivers who did not drive anyone else to another place before coming to work were more likely to shift their travel mode $(\mathrm{OR}=7.08)$ than other participants who did it 
(Table4.3, model 7). It shows that drivers of single occupant vehicles are more likely to change their mode of transportation in comparison with other drivers (i.e. Drivers who drive their kids to school).

\subsubsection{IMPACT OF AGE}

Ordered logit model shows that, participants who were less than 35 years old were more likely to change their mode of transportation $(\mathrm{OR}=5.26)$ than participants who were more than 50 years old (Table4.3, model 8). Recent forecasts estimate significant growth in Toronto's older adult population, from 26\% in 2011 to 36\% in 2041(Toronto Community Foundation, 2015). Agefriendly transportation alternatives in GTA may help to increase the older people willingness to change their mode, however it needs more research. 
Table 4.3. Ordered logit results

\begin{tabular}{|c|c|c|c|c|c|c|}
\hline \multicolumn{7}{|c|}{ Parameter Estimates } \\
\hline & & & Coef. $(\beta)$ & Std. Error & Odds Ratio & Sig. \\
\hline \multirow{4}{*}{$\frac{\bar{\theta}}{\frac{0}{8}}$} & \multirow{4}{*}{ 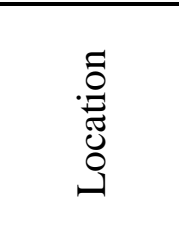 } & Liberty Village & 2.57 & .854 & 13.01 & .003 \\
\hline & & Downtown & 3.84 & .843 & 46.65 & .000 \\
\hline & & North York & 2.18 & .906 & 8.87 & .016 \\
\hline & & Richmond Hill & $0^{\mathrm{a}}$ & & & \\
\hline \multirow{4}{*}{$\frac{N}{\frac{N}{8}}$} & \multirow{4}{*}{ 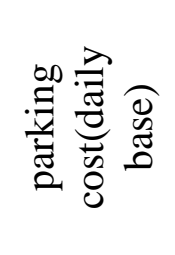 } & $\$ 20$ and more & 2.78 & .810 & 16.14 & .001 \\
\hline & & $\$ 10$ to $\$ 19.99$ & 2.39 & .650 & 10.87 & .000 \\
\hline & & Less than $\$ 10$ & 1.26 & .646 & 3.52 & .052 \\
\hline & & Free parkig & $0^{\mathrm{a}}$ & & & \\
\hline \multirow{5}{*}{$\frac{n}{\frac{0}{8}}$} & \multirow{5}{*}{ 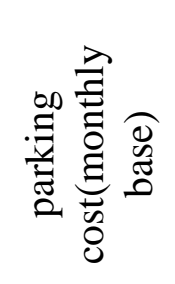 } & $\$ 200$ and more & 2.46 & .649 & 11.65 & .000 \\
\hline & & $\$ 150-\$ 199.99$ & 1.90 & .685 & 6.71 & .005 \\
\hline & & $\$ 100-\$ 149.99$ & 1.53 & .708 & 4.63 & .030 \\
\hline & & $\$ 50-\$ 99.99$ & 1.70 & .934 & 5.46 & .069 \\
\hline & & $0-\$ 49.99$ & $0^{\mathrm{a}}$ & & & \\
\hline \multirow{3}{*}{$\frac{\nabla}{\frac{\nabla}{8}}$} & \multirow{3}{*}{ 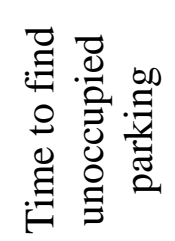 } & 0 to less than $2 \mathrm{~min}$ & -2.03 & .499 & 0.13 & .000 \\
\hline & & $2 \mathrm{~min}$ to less than $5 \mathrm{~min}$ & -1.42 & .458 & 0.24 & .002 \\
\hline & & $5 \mathrm{~min}$ and more & $0^{\mathrm{a}}$ & & & \\
\hline \multirow{2}{*}{$\frac{n}{\frac{n}{8}}$} & \multirow{2}{*}{ 㫕 } & Less than 4 hours & 0.32 & .446 & 1.38 & .467 \\
\hline & & 4 hours and more & $0^{\mathrm{a}}$ & & & \\
\hline
\end{tabular}


Table 4.3 (Continued)

\begin{tabular}{|c|c|c|c|c|c|c|}
\hline \multicolumn{7}{|c|}{ Parameter Estimates } \\
\hline & & & Coef. $(\beta)$ & Std. Error & Odds Ratio & Sig. \\
\hline \multirow{3}{*}{$\begin{array}{l}0 \\
\frac{0}{8} \\
\frac{0}{2}\end{array}$} & \multirow{3}{*}{$\begin{array}{l}\frac{0}{0} \\
0 \\
\frac{\pi}{0} \\
0 \\
0 \\
0 \\
0 \\
0\end{array}$} & One car & 1.94 & .661 & 6.98 & .003 \\
\hline & & Two cars & 1.33 & .609 & 3.76 & .030 \\
\hline & & More than two cars & $0^{\mathrm{a}}$ & & & \\
\hline \multirow{2}{*}{$\frac{1}{8}$} & \multirow{2}{*}{ 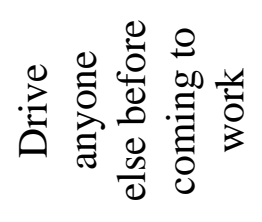 } & No & 1.96 & .590 & 7.08 & .001 \\
\hline & & Yes & $0^{\mathrm{a}}$ & & & \\
\hline \multirow{3}{*}{$\frac{\infty}{\frac{\infty}{0}}$} & \multirow{3}{*}{$\underset{<}{80}$} & Less than 35 & 1.66 & .538 & 5.26 & .002 \\
\hline & & 35 to 49 & -0.11 & .502 & 0.89 & .820 \\
\hline & & More than 50 & $0^{\mathrm{a}}$ & & & \\
\hline \multirow{5}{*}{$\frac{a}{\frac{a}{0}}$} & \multirow{5}{*}{ 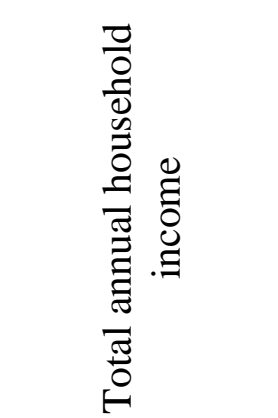 } & Under $\$ 10,000$ to $\$ 59,999$ & 1.16 & .905 & 3.18 & .201 \\
\hline & & $\$ 60,000$ to $\$ 79,999$ & 0.60 & .817 & 1.82 & .466 \\
\hline & & $\$ 80,000$ to $\$ 119,999$ & -0.05 & .821 & 0.95 & .952 \\
\hline & & More than $\$ 120,000$ & 1.17 & .975 & 3.21 & .231 \\
\hline & & I prefer not to say & $0^{\mathrm{a}}$ & & & \\
\hline
\end{tabular}

a.This parameter is set to zero because it is the reference. 


\section{CHAPTER FIVE: DISCUSSION AND CONCLUSIONS}

This chapter presents an overview of the key findings derived from ordered logit model outcomes and suggestions for future studies. Results from this research suggest that both parking pricing and parking availability play a significant role in regulating the mode of transportation by potentially shifting mode choice. Parking availability can also influence the impact of parking pricing increase on drivers' willingness to change their mode. As discussed in previous chapters, the impact of parking pricing and parking availability varies according to location. With regard to these factors of potential influence, our results suggest that annual household income and travel distance is uncorrelated with drivers' willingness to change their mode of transportation. However, these results may be GTHA-specific, and do not support some other studies conducted elsewhere that found and important association between income and the willingness to drive (Jou, Hensher, Liu, \& Chiu, 2010)

There were four questions and two research hypotheses described in chapter one, each of them concerning how drivers' transportation mode would change when parking pricing or parking availability changes. The overview of key findings in this section is divided according to the hypotheses and questions of the research.

\subsection{MODE SUBSTITUTION IS MORE LIKELY TO OCCUR FOR DRIVERS WHO PAY MORE FOR PARKING}

Findings from this research suggest that parking cost has a significant impact on commuters' willingness to change their mode of transportation. Results from the ordered logit model confirmed the first hypothesis that claimed that high price parking might encourage commuters to give up driving in favour of other alternative modes of travel. Furthermore, results suggest that 
participants who pay more for parking are much more likely to give up driving. Results show that drivers' willingness to change their mode of transportation, in response to parking cost increase, were influenced by current parking costs. However, in areas like Richmond Hill, where commuters parked their vehicles in free or underpriced parking lots, encouraging them to shift their mode by increasing the parking costs, should be combined with reducing the parking provision.

\subsection{PARKING AVAILABILITY MODERATES THE RELATIONSHIP BETWEEN PARKING PRICING AND A DRIVER'S WILLINGNESS TO CHANGE THEIR MODE}

According to the model results, availability of parking areas, changed the relationship between drivers' willingness to change their mode of transportation and parking pricing. It suggests that if parking availability is taken into account, the current parking cost becomes less relevant in relation to the decision to change the participants' mode of transportation. Results suggest that parking availability can play a significant role in regulating travel management by shifting mode choice.

\subsection{URBAN LOCATION IS IMPORTANT}

According to the results from the ordered logit model, there is a relationship between location and drivers' willingness to change their mode of transportation. Results suggest that drivers' willingness to change their mode of transportation was different in urban and suburban areas (Table 4.3, model 1). It shows that participants in urban areas, especially Downtown were more likely to shift their mode in comparison to suburban participants. Furthermore, it indicates that drivers in suburban areas are less price sensitive. The study results also highlight a major issue 
that needs consideration in transportation planning that most of the suburban respondents did not want to change their mode despite potential hikes in parking price. It may indicate that public transportation in suburban areas needs to be more accessible to be considered as a viable and economical alternative to driving.

The results also indicate that parking policies in suburban areas should be more focused on changing the travel mode choice by increasing parking pricing and decreasing parking supply. However, Increasing the parking pricing and reducing the parking provision should be done when the other alternative modes such as public transportation were available for commuters.

It is important that Uber has become a feasible alternative to public transit, once someone gives up driving especially in Downtown and Liberty Village. It seems that Uber has changed from a source of concerns to a reliable alternative. However, it needs more research on Uber impact on public transit as an alternative.

In conclusion, to reduce driving among commuters, a policy reform is required to change both parking pricing and parking availability in the GTA. Since most of participants in urban areas chose public transportation as a potential alternative to driving mode, changes in parking pricing and parking availability policies should also be coupled with public transportation improvements. It is clear that these changes should be done through a policy reform by planners. It is important for planners to answer why there are ample and underpriced parking in some areas of the city, especially in suburban areas.

As discussed in section two, policies such as parking cash-out programs, employee parking levies, unbundling parking and reducing the minimum parking requirement policy would decrease the parking supply which will help to reduce driving mode. Furthermore, 
municipalities, especially in suburban areas like Richmond Hill, should deregulate off street parking, remove the free parking areas and implement correct market price for on- street parking which allows invisible market forces to improve transportation and urban life. Policies to increase the parking cost should be done in a comprehensive reform to increase not only public off-street parking costs, but also all other available parking areas in the city.

This research makes a significant contribution to an emerging literature on the impact of parking pricing, and parking availability on travel mode and the results have important implications for future parking policies focused on travel mode change. Reform in parking policies in urban and suburban areas is an important area on which future studies should concentrate. 


\section{RYERSON UNIVERSITY}

\section{Consent to Participate in Research}

\section{THE ROLE OF PARKING PRICING AND PARKING AVAILABILITY ON TRAVEL MODE CHOICE}

\section{INTRODUCTION AND PURPOSE}

My name is Seyedmohsen Alavi. I am a graduate student at Ryerson University, working with my faculty supervisor, Professor Raktim Mitra, in the School of Urban and Regional Planning. I would like to invite you to take part in my research study. The purpose of this study is to understand how parking pricing and parking availability affect drivers travel modes, and how pricing and availability of parking spaces would change their mode of transportation.

Only if you drove and parked your vehicle for work or business purposes, you are eligible to complete this survey.

To complete this study, we need approximately 250 completed questionnaires by eligible participants. The results of this research will contribute to the Master Research Proposal, MRP, of Seyedmohsen Alavi and it may also be disseminated as a journal publication and academic presentation.

Your participation in this survey is voluntary. You may choose not to respond to any question or withdraw from the survey altogether anytime you want.

For further questions or concerns relating to this research project, please contact Seyedmohsen Alavi by email seyedmohsen.alavi@ ryerson.ca or Professor Raktim Mitra at 416-979-5000 ext. 2272, or by email raktim.mitra@ ryerson.ca.

WHAT YOU ARE BEING ASKED TO DO 
You are being asked to voluntarily complete this online survey. It involves questions about your purpose of trip and parking prices which you paid and should take about 15 minutes to complete. In order for all of your answers to be collected you must go to the end of the survey and click 'submit survey'. This will demonstrate your full consent to participation.

\section{POTENTIAL BENEFITS}

There is no direct benefit to you for taking part in this study. However, it is hoped that the data gained from the research may help planners and policy makers improve the parking system and commute options which may contribute to planning less car dependent and healthy communities.

\section{WHAT ARE THE POTENTIAL RISKS TO YOU}

Some of the survey questions may make you uncomfortable or upset, or you may simply wish not to answer some questions. You are free to decline to answer any questions you do not wish to answer, or stop participating at any time by closing your browser. If you close your browser before getting to the end of the survey and do not confirm your consent to participate at the end of the survey by clicking the 'submit' button your information collected up to that point will not be used.

\section{YOUR IDENTITY WILL BE ANONYMOUS}

The survey is anonymous and as such will not be collecting information that will easily identify you, like your name or other unique identifiers. Although your Internet Protocol (IP) address can be tracked through the survey platform, the researchers will not be collecting this information. Your IP address may be observed only to ensure that one individual is not completing the survey multiple times.

\section{HOW YOUR INFORMATION WILL BE PROTECTED AND STORED}

This survey uses Opinio and the servers are located in Canada, and data is hosted securely on the DMP server at Ryerson University which will increase the confidentiality and security.

To further protect your information, all downloaded survey data from datasets will be stored electronically on a password protected laptop and backed up to a password protected computer 
located in the Professor Mitra's research lab at Ryerson University campus, and no data will be shared electronically or personally to parties unrelated to the project. Only the researchers named in this study will have access to the data as collected. Any future publications will include collective information (i.e., aggregate data). Your individual responses (i.e. raw data) will not be shared with anyone outside of the research team.

Data will be stored for an upwards of 5 years and the data, which is completely anonymous, will be stored in a password protected computer in the Professor Mitra's research lab located on the Ryerson University campus to facilitate potential research in the period of 5 years. After five years all data files will be shredded, and contents of data files will be erased securely.

\section{INCENTIVE FOR PARTICIPATION}

You will not be paid for taking part in this study.

\section{YOUR RIGHTS AS A RESEARCH PARTICIPANT}

Participation in research is completely voluntary, and you can withdraw your consent at any point up to clicking the 'submit' button at the end of the survey. However, because the survey is anonymous, once you click the submit button at the end of the survey the researchers will not be able to determine which survey answers belong to you so your information cannot be withdrawn after that point.

Please note, that by clicking 'Accept' button at the end of this consent form, you are giving your consent for participation and you will be taken to the survey. By closing your browser at the end of this consent form, you will decline to participate in this study.

Please note, that by clicking 'Submit' button at the end of the survey you are providing your consent for participation, and you accepted that you have understood the purpose of this study. By consenting to participate, you are not waiving any of your legal rights as a research participant.

\section{QUESTIONS}

If you have any questions about this research, please feel free to contact Professor Raktim Mitra at 416-979-5000 ext. 2272, or by email raktim.mitra@ ryerson.ca 
If you have any questions about your rights or treatment as a research participant in this study, please contact the Ryerson University Research Ethics Board at rebchair@ ryerson.ca (416) 9795042.

Please print a copy of this page for your future reference.

By clicking 'Accept' you are giving your consent for participation and you will be taken to the survey. By closing your browser at the end of this consent form, you will decline to participate in this study

\section{Survey Questions}

"Questions 1 to 20 relates to the trip that ended with you parking your vehicle at the location where you received your survey invitation. Please answer these questions as they apply ONLY to this one trip.

1- What was the main purpose of your trip today?

○ Work nearby

○ Business nearby

○ Visiting for work or business purposes**

○ Other**

** If participants click on 'Other' then they will land on thanks, page: Thank you for participation. This study only focuses on work/business related travels.

2- Where did you park your car?

○ Public off-street parking garages or lot (where anyone can park a vehicle)

○ Private off-street parking garages or lot (i.e., reserved for employees of certain office/ business)

○ On-street parking space

○ Other ------

3- At which location was your vehicle parked today, when you collected our survey invitation?

○ Liberty Village

○ Downtown Toronto 
○ North York

○ Richmond Hill

4- How much time did it take you to find an unoccupied parking space to park your car?

○ No time at all (For example if you have a reserved parking spot)

○ 1 min to less than 2 min

- 2 min to less than 5 min

○ $5 \mathrm{~min}$ to less than $10 \mathrm{~min}$

○ 10 minutes and more

5- How long did it take you to walk from your parking space to the entrance of your workplace?

○ Less than 1 minute

- 1 min to less than 5 min

○ 5 min to less than $10 \mathrm{~min}$

- $10 \mathrm{~min}$ to less than $15 \mathrm{~min}$

- 15 minutes and more

6- How long did you park there?

- Less than 1 hour

- 1 hour to less than 2 hours

- 2 hours to less than 4 hours

- 4 hours to less than 6 hours

- 6 hours to less than 8 hours

○ 8 hours and more

7- When you drove to your work/business, how many people, including yourself, were in the car?

8- How much did parking your car cost you today (at the parking you see the flyer)? 

○ \$0 (parking was free)
○ $\quad \$ 1-\$ 4.99$
○ $\quad \$ 5-\$ 9.99$
○ \$10-\$14.99
○ \$15-\$19.99
○ \$20 and more

9- How much do you pay for parking (for work or business purposes) on a monthly basis?
○ $\quad 0$-\$49.99
○ \$50-\$99.99
○ $\$ 100-\$ 149.99$
○ $\quad \$ 150-\$ 199.99$
- \$200 and more

10 - If your daily parking price were up by $\$ 2$ per day (or 25 cents per hour), would you have driven your vehicle to work/ business today?
- Yes
- NO

* If participants click on 'Yes' then they will land on question 12 as the next branch question. ** If participants click on 'No' then they will land on question 11.A

10. A- which type of transportation would you choose instead of driving?
- Public Transportation
○ Cycling
○ Walking
○ Carpool
○ Other ------------

11- If your daily parking price were up by $\$ 4$ per day (or 50 cents per hour), would you have driven your vehicle to work/ business today?
- Yes
○ NO
* If participants click on 'Yes' then they will land on question 13. 
** If participants click on 'No' then they will land on question 12.A.

11. A- which type of transportation would you choose instead of driving?

○ Public Transportation

○ Cycling

○ Walking

- Carpool

○ Other -----------

12- If your daily parking price were up by $\$ 8$ per day (or $\$ 1$ per hour), would you have driven your vehicle to work/ business today?

- Yes

○ NO

* If participants click on 'Yes' then they will land on question 14.

** If participants click on 'No' then they will land on question 13.A.

12. A- which type of transportation would you choose instead of driving?
- Public Transportation
○ Cycling
○ Walking
○ Carpool
○ Other

13- If your daily parking price were up by $\$ 12$ per day (or $\$ 1.5$ per hour), would you have driven your vehicle to work/ business today?

○ Yes

○ NO

* If participants click on 'Yes' then they will land on question 15.

** If participants click on 'No' then they will land on question 14.A.

13. A- which type of transportation would you choose instead of driving?

- Public Transportation 
○ Cycling

○ Walking

○ Carpool

○ Other -----------

13.B- Please tell us why?

○ No other alternatives available

- Driving would be the cheapest alternative even after an increase in parking price 14- What is the nearest street intersection closest to your home?

○ City: ------

○ First street: ------

○ Second street: ------

15- What is the nearest street intersection to your work location?
○ City: ------
○ First street:
○ Second street: ------

16- Is driving your usual mode of travelling to work/ business?
- Yes
○ No

17- How many cars do you have in your household?
○ 1
○ 2
○ More than 2

18- Did you drive anyone else to another place before coming to work/business today?
- Yes
○ No

19- What is your age?
- 15-19
o 20 to 24
o 25 to 29
o 30 to 34
○ 35 to 39
o 40 to 44
o 45 to 49 o 50 to 54
○ 55 to 59
o 60 to 64
o 65 to 69 o 70 to 74
○ 75 to 79
o 80 to 84
o 85 to 89 o 90 and older 
19- Which of the following categories best describes your estimated total annual household income?

Under 10,000 o $\$ 10,000-\$ 19,999$ o $\$ 20,000-\$ 39,999$

○ $\$ 40,000-\$ 59,999$ о $\$ 60,000-\$ 79,999$ о $\$ 80,000-\$ 99,999$

- $\$ 100,000-\$ 119,999$ o $\$ 120,000-\$ 139,999$ o $\$ 140,000-\$ 159,999$

○ $\$ 160,000$ and over o I prefer not to answer

Thank you for your participation! 


\section{REFERENCE}

Alavi, M., Coutinho, W., Craig, C., Erl, C., Loewen, N., Smith, A., . . Tam, S. (2016). TRANSPORTATION OPTIONS FOR LIBERTY VILLAGE. School of Urban and Regional Planning Ryerson University. Toronto.

Auchincloss, A. H., Weinberger, R., Aytur, S., Namba, A., \& Ricchezza, A. (2015). Public Parking Fees and Fines: A Survey of U.S. Cities. Public Works Management \& Policy, 20(1), 49-59. doi:10.1177/1087724x13514380

Bao, D., Deng, W., \& Gu, S. (2010). Impact of Parking Rates on Resident Travel Behavior. Journal of Transportation Systems Engineering and Information Technology, 10(3), 8085. doi:http://dx.doi.org/10.1016/S1570-6672(09)60049-0

Bridgelall, R. (2014). Campus parking supply impacts on transportation mode choice.

Transportation Planning and Technology, 37(8), 711-737. doi:10.1080/03081060.2014.959354

Cairns, S., \& Arros, P. (2014). Policy Bundles for Reducing Transportation Emissions in Large Cities. Retrieved from http://www.sustainableprosperity.ca/sites/default/files/publications/files/TransportationB undles\%200ct\%202014.pdf

City of Toronto. (2015a). Official Plan. Retrieved from http://www1.toronto.ca/planning/chapters 1-5.pdf

City of Toronto. (2015b). Toronto Employment Survey 2015. Retrieved from https://www1.toronto.ca/City\%200f\%20Toronto/City\%20Planning/SIPA/Files/pdf/S/sur vey2015.pdf

City of Toronto. (2016). Citywide Zoning By-law Policy Areas. Retrieved from http://www1.toronto.ca/city_of_toronto/city_planning/zoning_environment/files/pdf/cit y-wide_Policy_Areas 569-2013_v2.pdf

D'Acierno, L., Gallo, M., \& Montella, B. (2006). Optimisation models for the urban parking pricing problem. Transport Policy, 13(1), 34-48. doi:http://dx.doi.org/10.1016/j.tranpol.2005.08.001

De Jong, J. (2012). THE IMPORTANCE OF ON-STREET PARKING TO BUSINESS VITALITY: A Study of Agricola Street, Halifax NS. Retrieved from https://www.halifax.ca/cycling/documents/Josh_dejong_Plan6000FinalPaper.pdf

Deakin, E., \& Harvey, G. (1996). Transportation Pricing Strategies for California: An Assessment of Congestion, Emissions, Energy, and Equity Impacts. Retrieved from http://www.arb.ca.gov/research/apr/past/92-316a.pdf

Gillen, D. W. (1977). Estimation and specification of the effects of parking costs on urban transport mode choice. Journal of Urban Economics, 4(2), 186-199. doi:http://dx.doi.org/10.1016/0094-1190(77)90022-5

Gragera, A., \& Albalate, D. (2016). The impact of curbside parking regulation on garage demand. Transport Policy, 47, 160-168. doi:http://dx.doi.org/10.1016/j.tranpol.2016.02.002

Hess, D. B. (2001). The Effects of Free Parking on Commuter Mode Choice: Evidence from Travel Diary Data. Retrieved from http://citycouncil.cityofdavis.org/Media/Default/Documents/PDF/CDD/Downtown-Parking-TaskForce/Mtg7/Att-3--Hess--Effect-of-Free-Parking-on-Commuter-Mode-Choice.pdf 
IBM Knowledge Center. (2016). Model (ordinal regression algorithms). Retrieved from http://www.ibm.com/support/knowledgecenter/SSLVMB_20.0.0/com.ibm.spss.statistics. help/alg_plum_model.htm

Jin, L., Searle, S., \& Lutsey, N. (2014). EVALUATION OF STATE-LEVEL U.S. ELECTRIC VEHICLE INCENTIVES. Retrieved from http://www.theicct.org/sites/default/files/publications/ICCT_state-EVincentives_20141030.pdf

Jou, R.-C., Hensher, D. A., Liu, Y.-H., \& Chiu, C.-S. (2010). Urban Commuters' Modeswitching Behaviour in Taipai, with an Application of the Bounded Rationality Principle. Urban Studies, 47(3), 650-665. doi:10.1177/0042098009351939

Kodransky, M., \& Hermann, G. (2011). Europe's Parking U-Turn: From Accommodation to Regulation. Retrieved from http://www.itdp.org/wpcontent/uploads/2014/07/Europes_Parking_U-Turn_ITDP.pdf

Kuzmyak, J. R., Pratt, R. H., Douglas, B., Spielberg, F., Administration, U. S. F. T., Board, N. R. C. T. R., \& Corporation, T. D. (2003). Traveler Response to Transportation System Changes: Land use and site design: Transportation Research Board.

Mackowski, D., Bai, Y., \& Ouyang, Y. (2015). Parking space management via dynamic performance-based pricing. Transportation Research Part C: Emerging Technologies, 59, 66-91. doi:http://dx.doi.org/10.1016/j.trc.2015.05.021

Metropolitan Area Planning Council. (2016). Parking and Transportation Demand Management. Retrieved from http://www.mapc.org/resources/parking-toolkit/strategies-topic/parking$\underline{\operatorname{tdm}}$

Mitra, R., Faulkner, G. E., Buliung, R. N., \& Stone, M. R. (2014). Do parental perceptions of the neighbourhood environment influence children's independent mobility? Evidence from Toronto, Canada. Urban Studies, 51(16), 3401-3419. doi:10.1177/0042098013519140

Ng, W.-S. (2014). Assessing the Impact of Parking Pricing on Transportation Mode Choice and Behavior. Retrieved from http://www.escholarship.org/uc/item/56f3v4wg

O'Connell, A. A. (2005). Logistic Regression Models for Ordinal Response Variables. Thousand Oaks, CA: SAGE Publications, Inc.

Pandhe, A., \& March, A. (2012). Parking availability influences on travel mode: Melbourne CBD offices. Australian Planner, 49(2), 161-171. doi:10.1080/07293682.2011.616177

Shoup, D. C. (2011). The high cost of free parking (Updated. ed.). Chicago: Planners Press, American Planning Association.

Toronto Community Foundation. (2015). Toronto's Vital Signs. Retrieved from https://torontofoundation.ca/sites/default/files/OP-TVS\%202015-Full-ReportPRINTING.pdf

Town of Richmond Hill. (2010). RichmondHillParkingStrategy. Retrieved from https://www.richmondhill.ca/documents/transportation_parking_strategy.pdf

Weinberger, R., Kaehny, J., \& Rufo, M. (2010). U.S. Parking Policies: An Overview of Management Strategies. Retrieved from https://www.itdp.org/wpcontent/uploads/2014/07/ITDP_US_Parking_Report.pdf

Wikipedia contributors. (2016, 1 August 2016 00:40 UTC). Ordinal regression. Retrieved from https://en.wikipedia.org/w/index.php?title=Ordinal_regression\&oldid=729211900

Willson, R. W., \& Shoup, D. C. (1990). Parking subsidies and travel choices: Assessing the evidence. Transportation, 17(2), 141-157. doi:10.1007/bf02125333 